Determination of Rock Properties by

Borehole-Geophysical and Physical-Testing

Techniques and Ground-Water Quality and

Movement in the Durham Triassic

Basin, North Carolina

U.S. GEOLOGICAL SURVEY PROFESSIONAL PAPER 1432 


\section{AVAILABILITY OF BOOKS AND MAPS OF THE U.S. GEOLOGICAL SURVEY}

Instructions on ordering publications of the U.S. Geological Survey, along with prices of the last offerings, are given in the current-year issues of the monthly catalog "New Publications of the U.S. Geological Survey." Prices of available U.S. Geological Survey publications released prior to the current year are listed in the most recent annual "Price and Availability List." Publications that are listed in various U.S. Geological Survey catalogs (see back inside cover) but not listed in the most recent annual "Price and Availability List" are no longer available.

Prices of reports released to the open files are given in the listing "U.S. Geological Survey Open-File Reports," updated monthly, which is for sale in microfiche from the U.S. Geological Survey, Books and Open-File Reports Section, Federal Center, Box 25425, Denver, CO 80225. Reports released through the NTIS may be obtained by writing to the National Technical Information Service, U.S. Department of Commerce, Springfield, VA 22161; please include NTIS report number with inquiry.

Order U.S. Geological Survey publications by mail or over the counter from the offices given below.

\section{BY MAIL}

\section{Books}

Professional Papers, Bulletins, Water-Supply Papers, Techniques of Water-Resources Investigations, Circulars, publications of general interest (such as leaflets, pamphlets, booklets), single copies of Earthquakes \& Volcanoes, Preliminary Determination of Epicenters, and some miscellaneous reports, including some of the foregoing series that have gone out of print at the Superintendent of Documents, are obtainable by mail from

\section{U.S. Geological Survey, Books and Open-File Reports Federal Center, Box 25425 Denver, CO 80225}

Subscriptions to periodicals (Earthquakes \& Volcanoes and Preliminary Determination of Epicenters) can be obtained ONLY from the

\section{Superintendent of Documents Government Printing Orfice Washington, D.C. 20402}

(Check or money order must be payable to Superintendent of Documents.)

\section{Maps}

For maps, address mail orders to

\section{U.S. Geological Survey, Map Distribution Federal Center, Box 25286 Denver, CO 80225}

Residents of Alaska may order maps from

\author{
Alaska Distribution Section, U.S. Geological Survey, \\ New Federal Building - Box 12 \\ 101 Twelfth Ave., Fairbanks, AK 99701
}

\section{OVER THE COUNTER}

\section{Books}

Books of the U.S. Geological Survey are available over the counter at the following Geological Survey Public Inquiries Offices, all of which are authorized agents of the Superintendent of Documents:

- WASHINGTON, D.C.--Main Interior Bldg., 2600 corridor, 18 th and C Sts., NW.

- DENVER, Colorado--Federal Bldg., Rm. 169, 1961 Stout St.

- LOS ANGELES, California--Federal Bldg., Rm. 7638, 300 N. Los Angeles St.

- MENLO PARK, California--Bldg. 3 (Stop 533), Rm. 3128, 345 Middlefield Rd.

- RESTON, Virginia--503 National Center, Rm. 1C402, 12201 Sunrise Valley Dr.

- SALT LAKE CITY, Utah--Federal Bldg., Rm. 8105, 125 South State St.

- SAN FRANCISCO, Callfornia--Customhouse, Rm. 504, 555 Battery St.

- SPOKANE, Washington--U.S. Courthouse, Rm. 678, West 920 Riverside Ave.

- ANCHORAGE, Alaska--Rm. 101, 4230 University Dr.

- ANCHORAGE, Alaska--Federal Bidg, Rm. E-146, 701 C St.

\section{Maps}

Maps may be purchased over the counter at the U.S. Geological Survey offices where books are sold (all addresses in above list) and at the following Geological Survey offices:

- ROLLA, Missouri--1400 Independence Rd.

- DENVER, Colorado--Map Distribution, Bldg. 810, Federal Center

- FAIRBANKS, Alaska--New Federal Bldg., 101 Twelfth Ave. 


\section{Determination of Rock Properties by}

Borehole-Geophysical and Physical-Testing Techniques and Ground-Water Quality and Movement in the Durham Triassic

\section{Basin, North Carolina}

By CHARLES E. BROWN

U.S. GEOLOGICAL SURVEY PROFESIONAL PAPER 1432

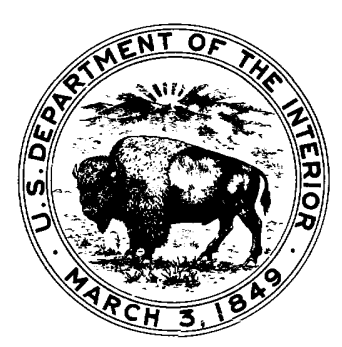




\section{DEPARTMENT OF THE INTERIOR \\ DONALD PAUL HODEL, Secretary}

\section{U.S. GEOLOGICAL SURVEY}

Dallas L. Peck, Director

Any use of trade names in this publication is for descriptive purposes only and does not imply endorsement by the U.S. Geological Survey

\section{Library of Congress Cataloging in Publication Data}

Brown, Charles E.

Determination of rock properties by borehole geophysical and physical-testing techniques, and ground-water quality and movement in the Durham Triassic basin, North Carolina.

(U.S. Geological Survey professional paper ; 1432)

Bibliography: $p$.

Supt. of Docs. no.: I 19.16:1432

1. Rocks, Sedimentary-North Carolina-Durham Region. 2. Geophysical well logging-North Carolina-Durham Region.

3. Geology, Stratigraphic-Triassic. 4. Water, Underground-North Carolina-Durham Region. 5. Geology-North Carolina-Durham Region. I. Title. II. Series.

$\begin{array}{lllll}\text { QE471.B788 } & 1988 & 557.56^{\prime} 563 & 85-600309 & \text { Rev. }\end{array}$

For sale by the Books and Open-File Reports Section, U.S. Geological Survey

Federal Center, Box 25425, Denver, CO 80225 


\section{CONTENTS}

\begin{tabular}{|c|c|c|c|}
\hline & & & \\
\hline & Page & & Page \\
\hline Abstract & 1 & Determination of rock properties by physical-testing & \\
\hline atroduction - - - - & 1 & & 16 \\
\hline Purpose and scope & 1 & Bulk density, moisture content, and effective porosity & 16 \\
\hline Description of study area & 1 & Permeability & 17 \\
\hline Location & 1 & Sonic velocity & 17 \\
\hline Geologic setting _ & 3 & Electrical resist & \\
\hline 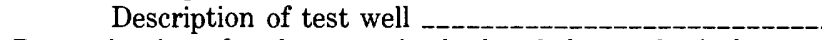 & 3 & Dechanical str & \\
\hline properties by borehole-geophysical & & Mecnanical strengtn & \\
\hline Descrintic & $\begin{array}{l}3 \\
3\end{array}$ & Evaluation of porosity and permeability measurements & \\
\hline $\begin{array}{l}\text { Description a } \\
\text { Spontane }\end{array}$ & $\begin{array}{l}3 \\
3\end{array}$ & $\begin{array}{l}\text { Porosity --_---1-- } \\
\text { Permeability }\end{array}$ & \\
\hline Resis & 3 & & \\
\hline Densi & 5 & $\begin{array}{l}\text { Determination of ground-water quality and movement } \\
\text { Water quality }\end{array}$ & 21 \\
\hline osity log _- & $\begin{array}{l}5 \\
8\end{array}$ & $\begin{array}{l}\text { Water quality } \\
\text { Chemical analysis of water samples }\end{array}$ & $\begin{array}{l}21 \\
21\end{array}$ \\
\hline - & 9 & Geophysical analysis & 21 \\
\hline ( & 11 & General quality & 21 \\
\hline eviewer log _ & 14 & Salinity & 21 \\
\hline Application of log data & 14 & Movement & 24 \\
\hline $\begin{array}{l}\text { Determination of lithology } \\
\text { Determination of secondary porosity }\end{array}$ & $\begin{array}{l}14 \\
14\end{array}$ & Conclusions -_-_-_- & \\
\hline Correlation of stratigraphic units in bas & 14 & Selected references & -28 \\
\hline
\end{tabular}

\section{ILLUSTRATIONS}

Plate 1. Geophysical log chart of the Sears No. 1 test well and laterolog of Groce No. 1 well

in pocket

Figures 1, 2. Maps showing:

1. Distribution of east coast Triassic basins _-_-_-_-_-_-_-_-_-_-_-_-

2. Durham Triassic basin and tectonic features

3-5. Graphs showing relation of:

3. Bulk density to sonic velocity for rocks in the Sears No. 1 well, North Carolina

4. Neutron porosity to sonic velocity for Triassic rocks in the Sears No. 1 well, North Carolina

5. Bulk density to apparent limestone porosity for rocks of the Sears No. 1 well, North Carolina

6-10. Graphs showing:

6. Correlation of temperature log with caliper and drilling sample logs

7. Temperature, differential temperature, caliper, and acoustic-televiewer logs, Sears No. 1 well, North Carolina

8. Relation of density to sonic velocity of cores of selected sandstone intervals

9. Plot of $M$ and $N$ parameters derived from geophysical logs for 640-m-depth to 1,140-m-depth interval _..._. 16

10. Plot of $M$ and $N$ parameters derived from geophysical logs for 152-m-depth to 640 -m-depth interval

11. Map showing ground-water-sample site locations in the Durham Triassic basin and Sears No. 1 well and Groce No. 1

well locations, North Carolina

12, 13. Graphs showing relation of:

12. Porosity determined from density $\log$ to resistivity and conductivity of rocks in the Sears No. 1 well, North Carolina

13. Porosity determined from sonic log to resistivity of rocks in the Sears No. 1 well, North Carolina 


\section{TABLES}

Page

TABLE 1. Log data from the Sears No. 1 well, North Carolina

5

2. Log crossplot data for the Sears No. 1 well, North Carolina

3. Porous zones (greater than $5 \mathrm{~m}$ thick) below $150-\mathrm{m}$ depth in the Sears No. 1 well, North Carolina

4. Rock characteristics processed from logs for the Sears No. 1 well, North Carolina

5. Sonic velocities and traveltimes for common materials and rocks of the Durham Triassic basin -

6. Physical properties of core samples from the Sears No. 1 well, North Carolina

7. Physical properties of core samples from the Deep River coal field, North Carolina _-_-_-_-_-_

8. Chemical analysis of ground water from the Sears No. 1 well, North Carolina

9. Chemical analysis of ground water from the Durham basin, North Carolina _-_____-

10. Formation water resistivities calculated by using laboratory measurements and porosity-log data, Sears No. 1 well, North Carolina

11. Formation water resistivities calculated by using spontaneous-potential-log data, Sears No. 1 well, North Carolina $-26$

12. Formation factors calculated from spontaneous-potential-log-derived water resistivities and from induction-log-derived true resistivities, Sears No. 1, North Carolina

\section{SYMBOLS AND ABBREVIATIONS}

\begin{tabular}{ll} 
Symbol & \multicolumn{1}{c}{ Definition } \\
& \\
$\mathrm{cm}^{3}$ & cubic centimeter \\
${ }^{\circ} \mathrm{C}$ & degree Celsius \\
${ }^{\circ} \mathrm{F}$ & degree Fahrenheit \\
$\Delta t$ & interval traveltime from sonic log \\
$\Delta t_{f}$ & interval traveltime from sonic log for fluid \\
$\Delta t_{m \prime}$ & interval traveltime from sonic log for matrix \\
$F$ & formation factor \\
$f$ & fluid \\
$\mathrm{g}$ & gram \\
$\mathrm{g} / \mathrm{cm}{ }^{3}$ & gram per cubic centimeter \\
$\gamma \mathrm{API}$ & gamma radiation reading, in American Petroleum \\
& $\quad$ Institute units \\
$\mathrm{HD}$ & hole diameter, in centimeters \\
$\mathrm{Hz}$ & hertz \\
$\mathrm{ILD}$ & deep induction log \\
$\mathrm{ILM}$ & medium-induction log \\
$\mathrm{K}$ & constant related to absolute temperature \\
$\mathrm{km}$ & kilometer \\
$\mathrm{kPa}$ & kilopascal \\
$\mathrm{LL} 8$ & shallow reading laterolog (laterolog 8$)$ \\
$\mathrm{L} / \mathrm{s}$ & liter per second \\
$M$ & lithology parameter based on interval traveltime and \\
& $\quad$ density \\
$\mathrm{m}$ & meter \\
$\mathrm{ma}$ & rock matrix \\
$\mu \mathrm{g} / \mathrm{L}$ & microgram per liter \\
$\mu \mathrm{m}{ }^{2}$ & intrinsic permeability, in square micrometers \\
&
\end{tabular}

\begin{tabular}{|c|c|}
\hline Symbol & Definition \\
\hline$\mu$ mho & micromho \\
\hline$\mu \mathrm{s}$ & microsecond \\
\hline$\mu \mathrm{s} / \mathrm{ft}$ & microsecond per foot \\
\hline $\mathrm{mg} / \mathrm{L}$ & milligram per liter \\
\hline $\mathrm{mV}$ & millivolt \\
\hline$\Omega \mathrm{m}$ & ohm-meter \\
\hline$N$ & $\begin{array}{l}\text { lithology parameter based on neutron-log porosity and } \\
\text { density-log porosity }\end{array}$ \\
\hline $\mathrm{pH}$ & negative $\log$ of hydrogen-ion activity porosity \\
\hline$\phi D$ & density-log porosity, in percent \\
\hline$\phi n$ & neutron-log porosity \\
\hline$\phi n_{f}$ & neutron-log reading for fluid \\
\hline$R_{m f}$ & resistivity of mud filtrate \\
\hline$R_{n}$ & $\begin{array}{l}\text { resistivity of formation sample } 100 \text { percent saturated } \\
\text { with fluid of } R_{u}\end{array}$ \\
\hline$R_{w}$ & resistivity of fluid in formation \\
\hline$R_{u e}$ & $\begin{array}{l}\text { Equivalent resistivity of water for high concentrations } \\
\text { of } \mathrm{NaCl}\end{array}$ \\
\hline Rt & true resistivity of a formation \\
\hline$\varrho b$ & bulk density of logged interval \\
\hline ef & fluid density \\
\hline s & second \\
\hline$S P$ & spontaneous potential \\
\hline SSP & $\begin{array}{l}\text { static } S P \text { (the deflection under ideal conditions opposite } \\
\text { a nonshaly formation) }\end{array}$ \\
\hline$T D S$ & total dissolved solids \\
\hline$V_{m u t}$ & matrix sonic velocity \\
\hline
\end{tabular}


Multiply metric unit

\author{
millimeter $(\mathrm{mm})$ \\ centimeter $(\mathrm{cm})$ \\ meter $(\mathrm{m})$ \\ kilometer $(\mathrm{km})$
}

cubic centimeter $\left(\mathrm{cm}^{3}\right)$

liter (L)

liter

$\operatorname{gram}(\mathrm{g})$

milligram (mg)

micromho ( $\mu$ mho)

liter per second $(\mathrm{L} / \mathrm{s})$

meter per second $(\mathrm{m} / \mathrm{s})$

kilogram per second $(\mathrm{km} / \mathrm{s})$

gram per cubic centimeter $\left(\mathrm{g} / \mathrm{cm}^{3}\right)$

milligram per liter $(\mathrm{mg} / \mathrm{L})$

microgram per liter $(\mu \mathrm{g} / \mathrm{L})$

degree Celsius $\left({ }^{\circ} \mathrm{C}\right)$ by

Length

0.3937

.3937

3.2808

.6214

Volume

0.06102

61.03

2.113

1.057

.2641

Weight

0.002205
.035

.000035

Conductance

1.0

Specific combinations

0.03531

3.281

3,281

62.43

.05841

.00005841

Temperature

$\left[\left(1.8 \times{ }^{\circ} \mathrm{C}\right)+32\right]$
To obtain inch-pound unit

inch (in)

inch

feet (ft)

mile (mi)

cubic inch $\left(\mathrm{in}^{3}\right)$

cubic inches

pints (pt)

quarts (qt)

gallon (gal)

pound, avoirdupois (lb avdp) ounce, avoirdupois (oz avdp) ounce, avoirdupois

microsiemen $(\mu \mathrm{S})$

cubic foot per second ( $\left.\mathrm{ft}^{3 / \mathrm{s}}\right)$

feet per second $(\mathrm{ft} / \mathrm{s})$

feet per second

pounds per cubic foot $\left(\mathrm{lb} / \mathrm{ft}^{3}\right)$

grain per gallon (gr/gal)

grain per gallon

degrees Fahrenheit $\left({ }^{\circ} \mathrm{F}\right)$ 



\title{
DETERMINATION OF ROCK PROPERTIES BY BOREHOLE-GEOPHYSICAL AND PHYSICAL-TESTING TECHNIQUES AND GROUND-WATER QUALITY AND MOVEMENT IN THE DURHAM TRIASSIC BASIN, NORTH CAROLINA
}

\author{
By Charles E. Brown
}

\begin{abstract}
Ground water in the Durham Triassic basin in North Carolina is present in suitable amounts for domestic supplies. Water for domestic supplies is usually confined to the upper 90 meters of porous and permeable Triassic rock. Below 90 meters only smaller amounts of additional potable water can be obtained. Ground water in Triassic rocks near the surface is in interstices that have been enlarged by weathering and by leaching of mineral cement. Chemical analyses indicate that water in the basin is a calcium bicarbonate-sodium sulfate type. The apparent resistivity of formation water in the Sears No. 1 test well indicates that water having a dissolved-solids concentration of less than 5,000 milligrams per liter is present in parts of the basin to a depth of at least 1,000 meters. However, the yield of water from the rocks at 1,000 meters or more is extremely small, and major supplies of ground water probably are not available at depths of more than 300 meters in the Durham Triassic basin.

Rocks in the basin consist chiefly of argillites and mudstones that have a high density and low matrix sonic velocity. Resistivity logs indicate an alternating-cyclic sequence of sandstones and massive shales. The average resistivity of the shale in the Sears No. 1 well is 40 to $50 \mathrm{ohm}$ meters; the sandstones and conglomerates have 5 to 10 times greater resistivity values. On the basis of gamma-ray logs, most of the sandstones have gamma-ray values of from 50 to 80 American Petroleum Institute units. The mean porosity, determined from the density log, is approximately 6 percent; the mean porosity laboratory value, determined from cores, is approximately 5 percent. The temperature gradient in the rocks of the Sears No. 1 well was estimated to be 1 degree Celsius per 66 meters. Borehole-geophysical data were very important in determining both the quantity and quality of water in potential aquifers of the Durham Triassic basin. These techniques can be used to investigate subsurface hydrogeologic conditions in other basins.
\end{abstract}

\section{INTRODUCTION}

The U.S. Geological Survey began a study to determine the effectiveness of borehole geophysical and physical rock properties analyses to define ground-water circulation and quality within the Durham Triassic basin. Borehole geophysics provided rapid geologic and hydrologic evaluation of aquifers. When these techniques are combined with laboratory analyses of rock properties and with other hydrologic tests, they can provide a comprehensive evaluation of ground-water movement and occurrence. This study is a part of a larger study begun in 1972 to investigate the feasibility of storing liquid wastes in Triassic rocks of the Durham Triassic basin ${ }^{1}$ of the Eastern United States.

\section{PURPOSE AND SCOPE}

This report presents the results of an investigation to (1) define the lithologic character and subsurface distribution of hydrogeologic units in the Durham Triassic basin, North Carolina, (2) identify and describe specific properties of rocks in the basin, and (3) describe water quality and circulation of ground water in the basin. These objectives were accomplished primarily by boreholegeophysical and laboratory analyses of rock and aquifer properties.

Although the study area encompasses the entire Durham Triassic basin of North Carolina, most geophysical and physical properties analyses were made from logs and cores of the Sears No. 1 test well, located east of the Wake County-Chatham County line in the central part of the basin.

\section{DESCRIPTION OF STUDY AREA}

\section{LOCATION}

Triassic basins are distributed along the Atlantic seaboard from Nova Scotia to Florida where they exist as buried basins. The basins extend eastward beneath the Cenozoic rocks onto the Continental Shelf where they are located by exploratory drilling and geophysical investigations. Figure 1 shows the location of east coast basins subparallel to the Appalachian trend. The Durham Triassic basin in North Carolina, which contains rocks of Upper Triassic age, is the southernmost exposed basin.

${ }^{1}$ Some of the east coast Triassic basins are now considered Triassic and Jurassic age but, for the purpose of this report, are called Triassic basins. 


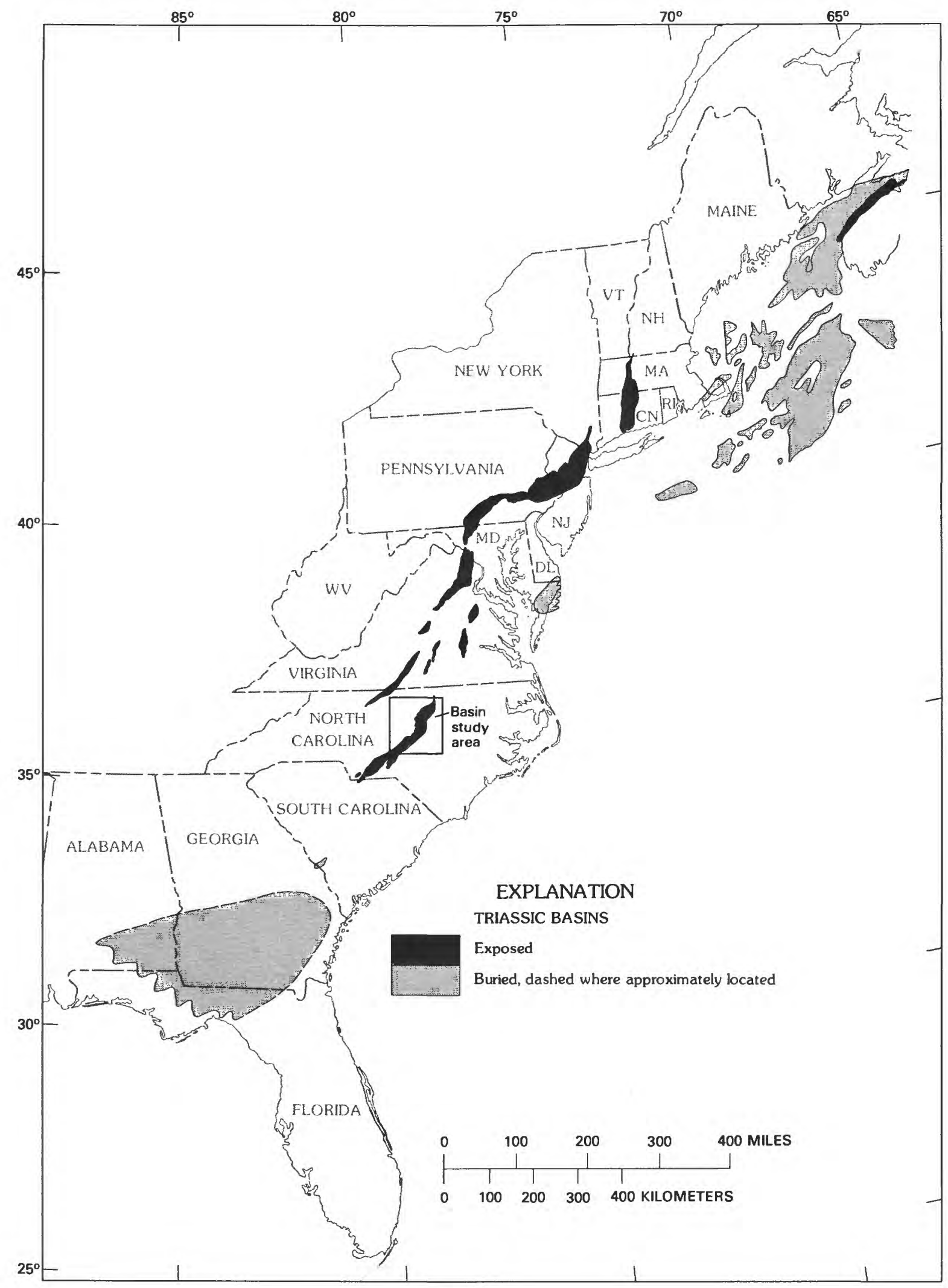

Figure 1.-Distribution of east coast Triassic basins. 
GEOLOGIC SETTING

The east coast Triassic basins are mostly half grabens or tilted grabens that contain sedimentary rocks of fluvial origin. The Durham Triassic basin is bounded on the east and southeast by a high-angle normal-fault zone known as the Jonesboro fault (fig. 2). The basin trends southwestward between the borders of North CarolinaVirginia and North Carolina-South Carolina. The basin is about $226 \mathrm{~km}$ long and averages about $16 \mathrm{~km}$ wide. The Durham Triassic basin is traditionally divided into four substructures, which from north to south are the Durham subbasin, the Colon cross structure, the Sanford or Deep River subbasin, and the Wadesboro subbasin (fig. 2).

\section{DESCRIPTION OF TEST WELL}

A deep test well was drilled by the U.S. Geological Survey in 1976 to a depth of $1,142 \mathrm{~m}$ in the Durham subbasin near New Hill, on the property of W.H. Sears (Sears No. 1). The test well was specifically designed and drilled to (1) verify surface and airborne geophysics data, (2) gain a knowledge of the subsurface geology, and (3) obtain hydrogeologic information on aquifer properties and fluids.

The lithologic log shown on plate 1 was prepared by using descriptions of drill cuttings sampled at $1.5-\mathrm{m}$ intervals. Cores were taken at five different intervals for determinations of physical properties. Results of physicalproperty tests are described and summarized in the section Determination of Rock Properties by PhysicalTesting Techniques. Borehole logs obtained at the completion of drilling (pl. 1) include temperature, neutron porosity, gamma ray, gamma-gamma density, sonic, dualinduction laterolog, microlog, caliper, and acoustic televiewer. Two zones in the test well were isolated with hydraulic packers to collect reservoir fluids for chemical analysis and to determine aquifer characteristics (Bain and Brown, 1981, for aquifer test data). Physical-property-test procedures by Terra Tek, Inc. ${ }^{2}$ (D.O. Ennis and S.W. Butters, written commun., 1976), are described in the section discussing laboratory analyses. The Triassic rocks drilled in the Sears No. 1 well can be grouped into at least three rock stratigraphic facies, from bottom to top: (1) a lower argillite-graywacke-conglomerate facies at least $122 \mathrm{~m}$ thick, (2) a 670-m-thick sequence of massive mudstone, argillite, and quartz conglomerate, and (3) a 640-m-thick sequence of arkosic sandstone, siltstone, and mudstone. These units do not necessarily correlate with the traditional boundaries of the Pekin, Cumnock, and Sanford Formations in another part of the Durham

${ }^{2}$ Use of brand and trade names in this report is for identification purposes only and does not constitute endorsement by the U.S. Geological Survey.
Triassic basin (Reinemund, 1955; Bain and Brown, 1981; and McKee and others, 1959).

The rocks drilled have low porosity and permeability, high average density, high velocity, high resistivity, and low gravity in contrast to the Piedmont crystalline rocks (pl. 1 and Bain and Brown, 1981).

\section{DETERMINATION OF ROCK PROPERTIES BY BOREHOLE-GEOPHYSICAL TECHNIQUES}

\section{DESCRIPTION AND INTERPRETATION OF GEOPHYSICAL LOGS}

\section{SPONTANEOUS-POTENTIAL LOG}

The spontaneous-potential (SP) log measures the natural electrical potential between the borehole fluid and the surrounding rock. Generally, the conductivity of the borehole fluid is less than that of the surrounding rock and causes apparent negative $S P$ deflections to the left opposite clean sand and to the right opposite shale. The $S P \log$ of the Sears No. 1 well shows several zones above 640-m depth where negative anomalies up to $40 \mathrm{mV}$ mark the occurrence of more permeable sandstones (pl. 1).

Between depths of $640 \mathrm{~m}$ and $990 \mathrm{~m}$, the $S P \log$ shows little contrast between the rock and borehole fluid and indicates increasing shaliness in the rocks. The lithologic $\log$ shows that the zone between 640 and $990 \mathrm{~m}$ consists of mudstone, massive argillite, and minor occurrence of conglomerate. Thus, the subdued character of the $S P$ curve in the $640-\mathrm{m}$ to $990-\mathrm{m}$ interval is caused by the shale content of the rock. A similar but much thinner facies occurs between depths of 308 and $338 \mathrm{~m}$. The negative $S P$ anomalies on the log below $990 \mathrm{~m}$ correspond to conglomerate on the lithologic log.

The $S P$ contrast between borehole and formation fluids is used elsewhere in this paper to predict total dissolvedsolids (TDS) content of the formation waters. The general subdued character of the $S P$ curve indicates that formation fluids are not much more saline than the fluid in the borehole. Because the dissolved-solids content in the drilling mud was less than $300 \mathrm{mg} / \mathrm{L}$ throughout the drilling, the Sears No. 1 well probably did not penetrate rock containing extremely saline fluids.

\section{RESISTIVITY LOGS}

The resistivity of a rock depends on the resistivity of the rock-mineral matrix and its contained fluids. Rocks that are composed primarily of quartz and feldspar, which are poor conductors, contain water that is usually a better conductor. Thus, the resistivity of a sandstone generally is largely related to the amount and the geometry of its pore space and to the salinity of its contained 


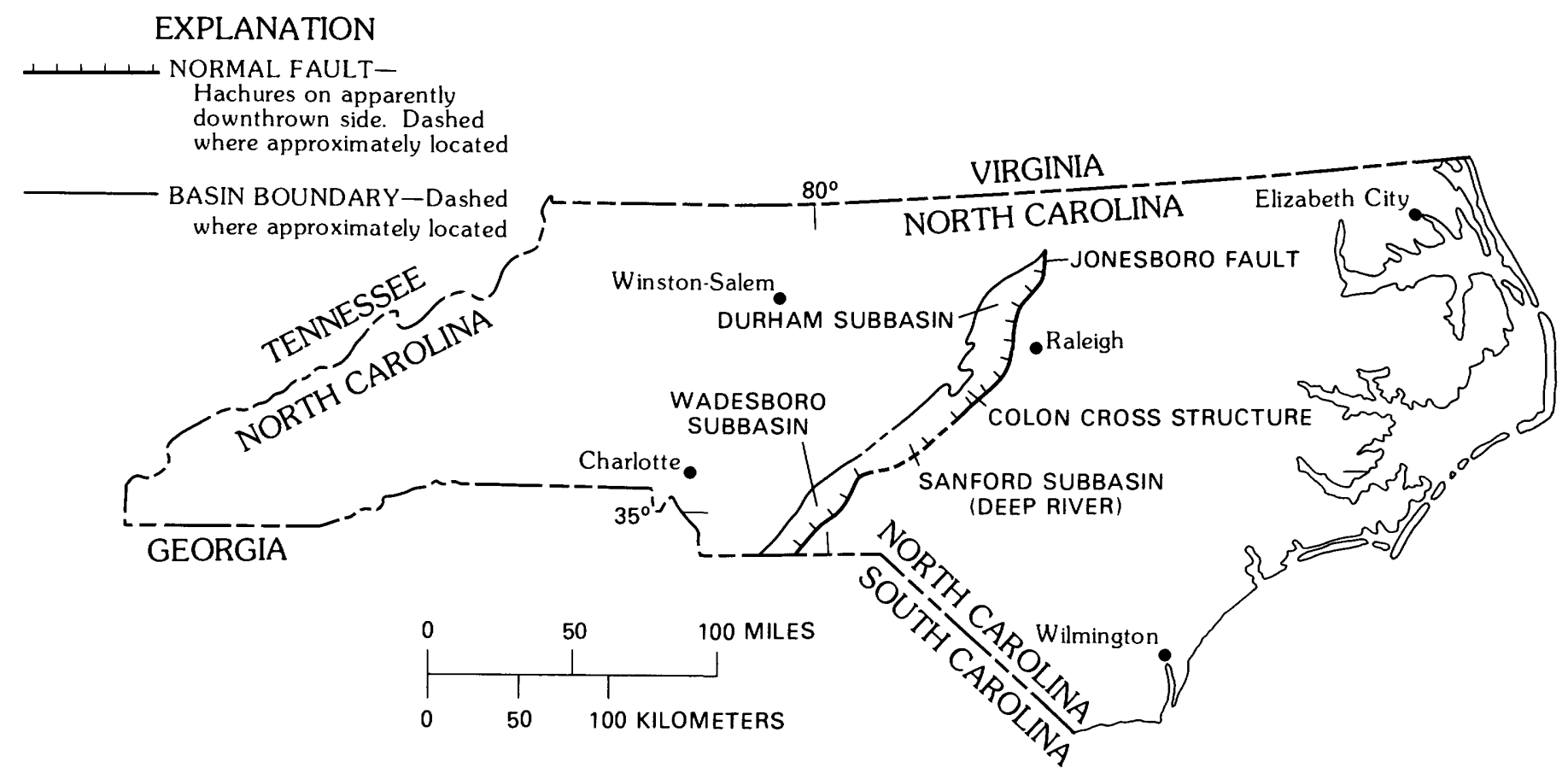

Figure 2. - Durham Triassic basin and tectonic features. See figure 11 for well and town locations.

fluid. As rock porosity decreases, formation resistivity on the whole increases, assuming that the resistivity of the formation fluid remains constant.

Five separate types of resistivity logs were run in the Sears No. 1 well: microlog, microlaterolog, laterolog 8 (LL8), medium-induction log (ILM), and deep-induction $\log$ (ILD). Resistivity on these logs is expressed in square ohm-meters per meter or, more commonly, ohm-meters $(\Omega m)$.

The microlog depicts the resistivity of the mudcake covering a permeable zone. The laterolog and mediumand deep-induction logs depict resistivities for zones away from the borehole. The deep-induction $\log$ is used to provide a more reliable value for the true rock resistivity in those situations where invasion by drilling fluid has occurred in the rock. In some cases, resistivity of the flushed zone next to the borehole can be determined from a microlaterolog (available for Sears No. 1 well).

The log response to the difference in resistivity of different lithologies is useful in determining the vertical distribution and thickness of rock types. Conventionally, some type of resistivity curve (pl. 1) is recorded with the $S P \log$. The $S P$-resistivity log combination is useful in ground-water investigations for identifying the more permeable, water-yielding zones. In an area of fresh ground water, a water-yielding zone has a large negative (left) deflection on the $S P$ curve. Examples of such opposing deflections occur on the logs of Sears No. 1 well at 192-, 229-, and 250-m depths (pl. 1).
In permeable zones, drilling mud enters the formations and displaces the formation fluid because the drilling mud maintains a higher hydrostatic head. Thus, the depth of mud invasion is a qualitative measure of permeability. The four types of logs shown on plate 1 have different depths of investigation. The dual (medium- and deep-) inductionlaterolog combination is specifically designed to determine the depth of mud invasion. In table 1 the known effect of mud invasion on the true resistivity $(R t)$ of the formation is compensated for by using the ratio of the resistivities of the ILD, ILM, and LL8 to each other (see Schlumberger, Ltd., 1977, p. 50). In columns 2 and 3 of table 2 , the values for the LL8 and ILD give a qualitative estimate of invasion of the formation by the drilling fluid, when resistivity values from the ILD and LL8 are different. The resistivity values from the ILD and LL8 will be approximately equal when no drilling fluid invasion has occurred.

The resistivity $\operatorname{logs}$ reveal a cyclic or alternating sequence of sandstones and massive shales. The average resistivity of shale on the deep-induction log curve is about 40 to $50 \Omega \mathrm{m}$ throughout the well. The sandstones and conglomerates, however, are typically 5 to 10 times more resistive. One sandstone or conglomerate is $10 \mathrm{~m}$ thick near a depth of $793 \mathrm{~m}$, but the vast majority of the sandstones are 0.67 to $3 \mathrm{~m}$ in thickness. If the lithologies of the well are arbitrarily divided into sandstone and shale, the ratio of sandstone to shale is approximately $2: 3$ (pl. 1). 
TABLE 1.-Log data from the Sears No. 1 well, North Carolina

\begin{tabular}{|c|c|c|c|c|}
\hline $\begin{array}{l}\text { Log } \\
\text { depth, } \\
\text { center } \\
\text { of zone } \\
(\mathrm{m})\end{array}$ & $\begin{array}{c}\text { True } \\
\text { resistivity, } \\
\text { from deep- } \\
\text { induction log } \\
(\Omega \mathrm{m})\end{array}$ & $\begin{array}{c}\text { Sonic } \\
\text { velocity } \\
(\mathrm{km} / \mathrm{s})\end{array}$ & $\begin{array}{c}\text { Bulk } \\
\text { density } \\
\left(\mathrm{g} / \mathrm{cm}^{3}\right)\end{array}$ & $\begin{array}{l}\text { Porosity } \\
\text { (percent) }\end{array}$ \\
\hline 155 & 140 & 3.79 & 2.45 & 14 \\
\hline 192 _ & 220 & 3.72 & 2.48 & 10.2 \\
\hline 220 & 200 & 3.91 & 2.46 & 13 \\
\hline 229 & 120 & 3.72 & 2.45 & 13.4 \\
\hline 233 & 50 & 3.86 & 2.45 & 13 \\
\hline 242 & 55 & 4.12 & 2.55 & 8 \\
\hline 248 & 28 & 3.46 & 2.42 & 16 \\
\hline 258 & 45 & 3.81 & 2.50 & 11 \\
\hline 273 & 25 & 3.81 & 2.4 & 15.5 \\
\hline 279 & 39 & 3.57 & 2.42 & 16 \\
\hline 289 & 69 & 4.18 & 2.46 & 13 \\
\hline 339 & 65 & 4.42 & 2.5 & 8 \\
\hline 350 & 75 & 4.18 & 2.65 & 2 \\
\hline 353 & 95 & 4.12 & 2.45 & 12 \\
\hline 378 & 38 & 4.23 & 2.48 & 10.1 \\
\hline 399 & 64 & 4.12 & 2.46 & 13.6 \\
\hline 414 & 65 & 4.26 & 2.56 & 8.3 \\
\hline 440 & 90 & 4.48 & 2.50 & 10 \\
\hline 477 _- & 47 & 4.45 & 2.45 & 13 \\
\hline 508 & 190 & 4.84 & 2.58 & 5 \\
\hline 527 & 120 & 4.88 & 2.60 & 3 \\
\hline 570 & 100 & 4.84 & 2.57 & 6 \\
\hline 583 & 140 & 4.84 & 2.57 & 7 \\
\hline 610 & 170 & 5.00 & 2.70 & 1 \\
\hline 633 & 130 & 4.92 & 2.55 & 8 \\
\hline 999 - & 100 & 5.17 & 2.67 & .6 \\
\hline 1,020 & 150 & 5.21 & 2.68 & 0 \\
\hline 1,041 & 250 & 5.35 & 2.67 & -.1 \\
\hline 1,056 & 375 & 5.40 & 2.68 & 0 \\
\hline 1,082 & 160 & 5.54 & 2.69 & -1.5 \\
\hline 1,096 & 63 & 4.62 & 2.70 & -1 \\
\hline 1,105 & 200 & 5.00 & 2.72 & -3 \\
\hline 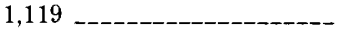 & 150 & $\underline{4.92}$ & $\underline{2.65}$ & 1.8 \\
\hline Mean $=$ & & 4.45 & 2.55 & 7.48 \\
\hline Standard deviation $=$ & 76.3 & .586 & .101 & 5.90 \\
\hline No. of samples $=$ & 33 & 33 & 33 & 33 \\
\hline
\end{tabular}

The lithologic log and the gamma-ray logs also exhibit a cyclic pattern. This pattern is most pronounced at depths between 732 and $793 \mathrm{~m}$ and depths between 915 and $960 \mathrm{~m}$ where the microlog shows an inverted stairstep character. Cycle frequency on the log is about $5.5 \mathrm{~m}$, and resistivity amplitude is about one order of magnitude. The cycles start at the bottom of the well at a very resistive conglomerate that becomes fine grained progressively upward into massive red argillite or mudstone. Similar cycles are also apparent higher in the hole, such as at the 518-m-depth to 427 -m-depth interval.

Cycles on the logs having a frequency of 3 to $6 \mathrm{~m}$ can also be identified in the upper, more sandy part of the well. Here, however, the change in grain size from coarse to fine is much more abrupt, and the sandstones are better sorted.

The conglomeratic-argillite sequence probably formed as a normal consequence of sedimentary debris settling out of periodic influxes of coarse sediment in- to standing water. These periodic influxes might be caused by the erosion of an uplifted fault block. The abrupt change from coarse to fine in the upper part of the hole could result from changes in stream deposition and channel erosion processes (Reinemund, 1955; Bain and Brown, 1981).

\section{DENSITY-POROSITY LOG}

The gamma-gamma density log measures the apparent density of the borehole environment by recording the loss of gamma radiation caused by collision with electrons of the rock matrix and contained fluids. The attenuation of gamma radiation from the tool source depends on the electron density of the formation. Bulk density in grams per cubic centimeter depends, therefore, on porosity and the electron density of the rock matrix and fluid. In practice, a shielded gamma-ray source is pressed against and moved along the borehole wall. The attenuated radiation is received at two points at different distances from the source to adjust for the effect of mud thickness and irregular hole diameter. The density-porosity curve of plate 1 has been adjusted electronically for mud thickness and hole diameter changes, except where large washouts of wellbore have occurred.

The density log confirms the dense nature of the rocks and their characteristically low porosity. Recorded densities range from an average $2.55 \mathrm{~g} / \mathrm{cm}^{3}$ to $2.70 \mathrm{~g} / \mathrm{cm}^{3}$ below a depth of $610 \mathrm{~m}$. The massive argillaceous rocks are the densest beds above the $610-\mathrm{m}$ depth. Below $610 \mathrm{~m}$ in depth, the sandstones and siltstones appear to be as dense if not more dense than the argillaceous rocks.

Bulk density and corresponding porosity have been selected from the density log at points where the borehole is relatively free of washouts. These values are presented in table 2 for direct comparison with porosity determined from the neutron and sonic logs.

The density log indicates very little primary porosity between 655 and $905 \mathrm{~m}$. Sandstones and conglomerate at depths of $833,911,1,020,954,1,110$, and $1,131 \mathrm{~m}$ have low apparent porosities of up to 4 percent. The $S P$-log response for these points indicates that water is present in the formation.

\section{NEUTRON-POROSITY LOG}

The neutron-logging tool (in this case, the sidewall neutron-porosity tool) consists of a neutron source and a shielded neutron detector that are pressed against and moved down the borehole. The principle of neutron logging is that high-energy, electrically neutraI particles are emitted from a radioactive source and collide with the nuclei of atoms of the surrounding environ- 
TABLE 2.-Log crossplot data for the Sears No. 1 well, North Carolina

[LL8, laterolog 8; ILD, deep-induction $\log ; H D$, hole diameter, in $\mathrm{cm} ; \gamma$ API, gamma radiation, in API units; $\phi D$, density-log porosity, in percent; $e^{b}$, bulk density, in g/cm; $\Delta t$, interval traveltime from sonic $\log$, in $\mu \mathrm{s} / \mathrm{ft} ; \phi n$, neutron-log porosity, in percent; $M$, parameter calculated: $\left((189-\Delta t) /\left(\rho^{b-1.0)) \times 0.01 ;} N\right.\right.$, parameter caiculated: $(1.0-\phi n) /(\varrho b-1.0)$; sonic-log porosity calculated: $\left(\left(\Delta t-\Delta t_{m u}\right)\left(\Delta t_{1}-\Delta t_{m+t}\right)\right) ; m a$, rock matrix; $f$, fluid; $S P$, spontaneous potential;,- no data]

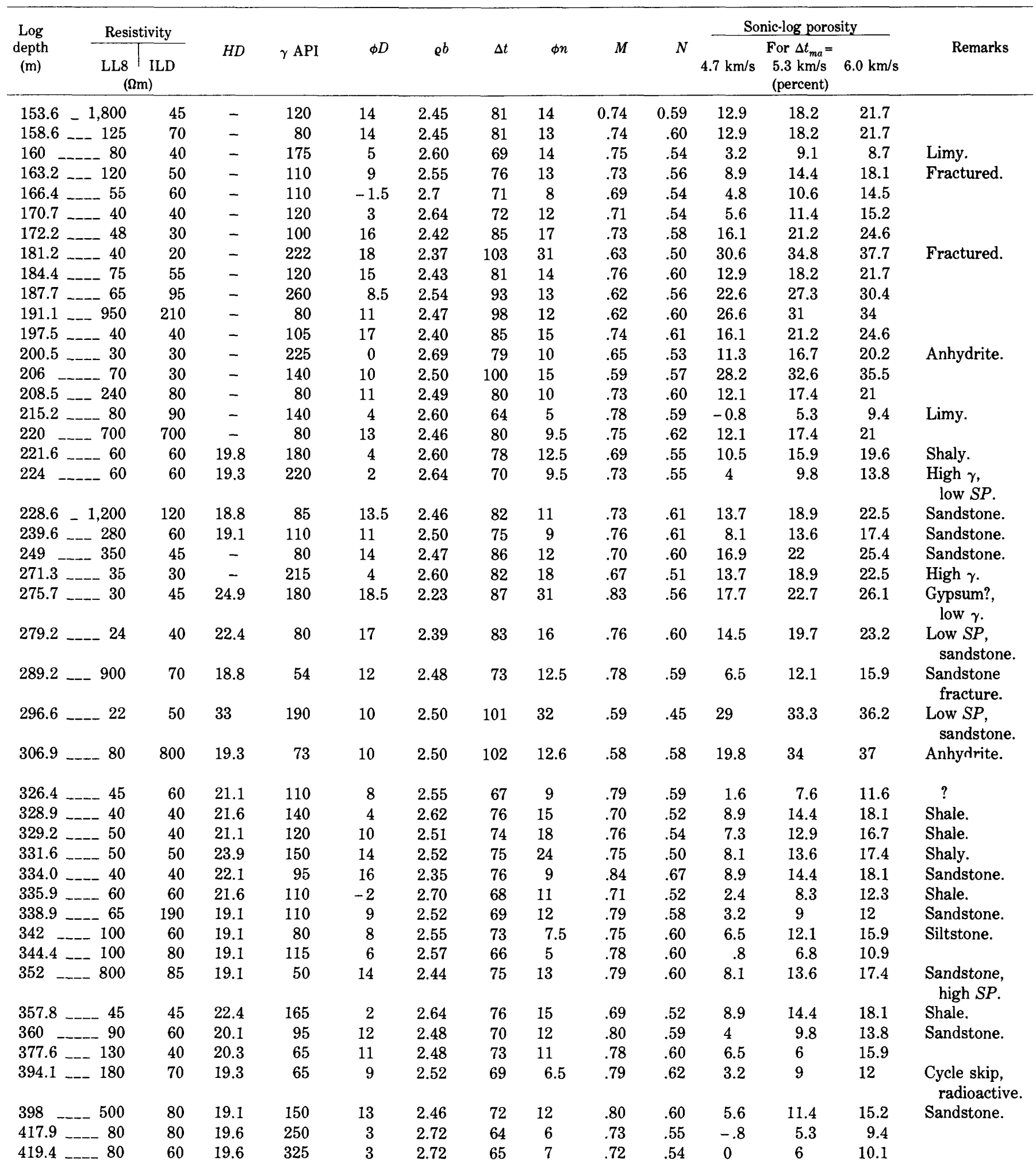


TABLE 2.-Log crossplot data for the Sears No. 1 well, North Carolina-Continued

\begin{tabular}{|c|c|c|c|c|c|c|c|c|c|c|c|c|c|c|}
\hline \multirow{3}{*}{$\begin{array}{c}\begin{array}{c}\log \\
\text { depth } \\
(\mathrm{m})\end{array} \\
440.4\end{array}$} & \multicolumn{2}{|c|}{ Resistivity } & \multirow[b]{2}{*}{$H D$} & \multirow[b]{2}{*}{$\gamma \mathrm{API}$} & \multirow[b]{2}{*}{$\phi D$} & \multirow[b]{2}{*}{$\mathrm{e}^{b}$} & \multirow[b]{2}{*}{$\Delta t$} & \multirow[b]{2}{*}{$\phi n$} & \multirow[b]{2}{*}{$M$} & \multirow[b]{2}{*}{$N$} & \multicolumn{3}{|c|}{ Sonic-log porosity } & \multirow[b]{2}{*}{ Remarks } \\
\hline & $\begin{array}{r}\text { LL8 } \\
\quad(\Omega \mathrm{n}\end{array}$ & ILD & & & & & & & & & $4.7 \mathrm{~km} / \mathrm{s}$ & $\begin{array}{c}\text { For } \Delta t_{m q}= \\
5.3 \mathrm{~km} / \mathrm{s} \\
\text { (percent) }\end{array}$ & $6.0 \mathrm{~km} / \mathrm{s}$ & \\
\hline & -_- 90 & 70 & 19.3 & 55 & 10 & 2.50 & 69 & 9 & 0.80 & 0.61 & 3.2 & 9 & 13 & \\
\hline 449.2 & $\ldots 50$ & 60 & 21.9 & 60 & 14 & 2.45 & 75 & 14 & .79 & .59 & 8.1 & 13.6 & 17.4 & $\begin{array}{l}\text { Low } S P \text {, } \\
\text { sandstone. }\end{array}$ \\
\hline 465.1 & $-\ldots 80$ & 80 & 20.3 & 80 & 15 & 2.60 & 64 & 7 & .78 & .58 & -.8 & 5.3 & 9.4 & \\
\hline 488.9 & - 60 & 50 & 19.1 & 70 & 11 & 2.49 & 67 & 10.5 & .82 & .60 & 1.6 & 7.6 & 11.6 & Sandstone. \\
\hline 495.9 & - 50 & 60 & 19.8 & 150 & 2 & 2.64 & 67 & 13 & .74 & .53 & 1.6 & 7.6 & 11.6 & Shaly. \\
\hline 498.9 & -_-_ 80 & 90 & 18 & 230 & 9 & 2.53 & 67 & 7 & .80 & .61 & 1.6 & 7.6 & 11.6 & Sandy. \\
\hline 500.8 & ---80 & 60 & 18 & 76 & 9 & 2.52 & 63 & 7 & .83 & .61 & -1.6 & 4.5 & 8.7 & Sandstone. \\
\hline 508.4 & --- 120 & 120 & 18 & 90 & 2 & 2.7 & 59 & 4 & .81 & .60 & -4.8 & 1.5 & 5.9 & $\begin{array}{l}\text { Limy, } \\
\text { sandstone. }\end{array}$ \\
\hline 526.1 & -_- 70 & 100 & 18 & 220 & 0 & 2.68 & 64 & 8 & .74 & .55 & -.8 & 5.3 & 9.4 & High $\gamma$ \\
\hline 534.6 & --- 70 & 90 & 19.1 & 90 & 10 & 2.54 & 65 & 6 & .80 & .61 & 0 & 6 & 10.1 & Sandstone. \\
\hline 549.8 & -_- 50 & 50 & 19.1 & 60 & 12 & 2.49 & 64 & 11 & .84 & .60 & -.8 & 5.3 & 9.4 & Sandstone. \\
\hline 550.4 & -300 & 60 & 30.5 & 140 & 22 & 1.85 & 82 & 45 & 1.27 & .67 & 13.7 & 18.9 & 22.5 & Fractured. \\
\hline 569.3 & $-\ldots 90$ & 90 & 19.3 & 215 & 2 & 2.63 & 67 & 11 & .75 & .55 & 1.6 & 7.6 & 11.6 & High $\gamma$ \\
\hline 570.9 & -- 100 & 100 & 18.3 & 250 & 16 & 2.42 & 72 & 15 & .82 & .60 & 5.6 & 11.4 & 15.2 & High $\gamma$. \\
\hline 576.3 & --- 70 & 80 & 18.8 & 225 & 1 & 2.65 & 64 & 7 & .76 & .56 & -.8 & 5.3 & 9.4 & High $\gamma$. \\
\hline 581.5 & -_- 60 & 70 & 18 & 90 & 9 & 2.52 & 66 & 6 & .81 & .62 & .8 & 6.8 & 10.9 & Siltstone. \\
\hline 585.2 & --- 120 & 125 & 17.8 & 220 & 9 & 2.54 & 62 & 5 & .82 & .62 & -2.4 & 3.8 & 8 & Sandstone. \\
\hline 596.8 & $-\ldots 200$ & 140 & 18.6 & 80 & 8 & 2.55 & 61 & 9 & .83 & $: 59$ & -3.2 & 3 & 7.2 & Siltstone. \\
\hline 609.6 & --300 & 170 & 17.8 & 70 & -2 & 2.70 & 57 & 3 & .78 & .57 & -6.5 & 0 & 4.3 & \\
\hline 619.3 & ---50 & 55 & 19.6 & 140 & 0 & 2.68 & 73 & 10 & .69 & .54 & 6.5 & 12.1 & 15.9 & Shale. \\
\hline 624.5 & - 70 & 80 & 18.0 & 75 & 8 & 2.54 & 65 & 7 & .80 & .60 & 0 & 6 & 10.1 & Sandstone. \\
\hline 638.2 & ---200 & 130 & 18.3 & 100 & 0 & 2.70 & 59 & 3.5 & .76 & .57 & -4.8 & 1.5 & 5.8 & \\
\hline 639.4 & $\ldots 50$ & 60 & 18.3 & 130 & 0 & 2.67 & 70 & 12 & .71 & .53 & 4 & 9.8 & 13.8 & Shale. \\
\hline 641.9 & --- 100 & 105 & - & 70 & 7 & 2.58 & 61 & 5 & .81 & .60 & -3.2 & 3 & -7.2 & $\begin{array}{c}\text { Very low } S P \\
\text { sandstone. }\end{array}$ \\
\hline 654.7 & $-\ldots 70$ & 90 & - & 100 & -1 & 2.70 & 62 & 6 & .75 & .55 & -2.4 & 3.8 & 8 & Siltstone. \\
\hline 670.5 & -. 120 & 120 & 17.3 & 70 & 1 & 2.67 & 59 & 5.5 & .78 & .57 & -4.8 & 1.5 & 5.8 & Conglomerate. \\
\hline 694.9 & -_- 70 & 65 & 19.6 & 100 & 1 & 2.68 & 68 & 14 & .72 & .51 & 2.4 & 8.3 & 12.3 & Shale. \\
\hline 696.7 & --- 180 & 90 & 18 & 65 & 2 & 2.65 & 59 & 5 & .79 & .58 & -4.8 & 1.5 & 5.8 & $\begin{array}{l}\text { Limy, con- } \\
\text { glomerate. }\end{array}$ \\
\hline 715.6 & $\ldots 80$ & 65 & 20.3 & 90 & 4 & 2.6 & 63 & 9 & .79 & .57 & -1.6 & 4.5 & 8.7 & Shale. \\
\hline 742.5 & --50 & 50 & 20.3 & 95 & 6 & 2.55 & 72 & 16 & .75 & .54 & 5.6 & 11.4 & 15.2 & Shale. \\
\hline 743.1 & ----35 & 45 & 21.3 & 100 & 0 & 2.65 & 71 & 15 & .72 & .52 & 4.8 & 10.6 & 14.5 & Shale. \\
\hline 743.7 & ----50 & 50 & 19.3 & 85 & 0 & 2.68 & 65 & 12 & .74 & .52 & 0 & 6 & 10.1 & Shale. \\
\hline 744.3 & --- 70 & 70 & 18.8 & 85 & 0 & 2.68 & 62 & 8 & .76 & .55 & -2.4 & 3.8 & 2 & \\
\hline 744.9 & $-\ldots 100$ & 100 & 18.3 & 60 & 3 & 2.62 & 64 & 8 & .77 & .57 & -.8 & 5.3 & 9.4 & \\
\hline 788.9 & -_- 150 & 120 & 17.8 & 60 & 1 & 2.66 & 60 & 5 & .78 & .57 & -4 & 2.2 & 6.5 & Conglomerate. \\
\hline 828.4 & -.- 110 & 110 & 17.3 & 60 & 1 & 2.66 & 59 & 6 & .78 & .57 & -4.8 & 1.5 & 5.8 & Conglomerate \\
\hline 853.4 & -._ 70 & 80 & 18.3 & 90 & -1 & 2.70 & 64 & 9.5 & .74 & .53 & -.8 & -5.3 & 9.4 & \\
\hline 882.7 & ---160 & 70 & 16.8 & 70 & 3 & 2.52 & 59 & 6 & .86 & .62 & -4.8 & 1.5 & 5.8 & \\
\hline 907 & --- 100 & 80 & 17.3 & 60 & 4 & 2.61 & 59 & 9 & .81 & .57 & -4.8 & 1.5 & 5.8 & \\
\hline 917.1 & --- 50 & 50 & 17.8 & 95 & 0 & 2.70 & 65 & 9.5 & .73 & .53 & 0 & 6.0 & 10.1 & \\
\hline 925.3 & --- 190 & 110 & 17.3 & 60 & 5 & 2.60 & 57 & 4 & .82 & .60 & -6.5 & 0 & 4.3 & Conglomerate. \\
\hline 936.9 & --- 50 & 60 & - & 100 & -1 & 2.69 & 66 & 10 & .73 & .53 & .8 & 6.8 & 10.9 & \\
\hline 946.1 & -_ 500 & 210 & - & 60 & 1 & 2.66 & 57 & 4 & .80 & .58 & -.65 & 0 & 4.3 & \\
\hline 976.8 & ---40 & 30 & - & 105 & 50 & 1.65 & 76 & 42 & 1.74 & .89 & 8.9 & 14.3 & 18.1 & \\
\hline $1,019.2$ & --600 & 150 & - & 70 & 0 & 2.68 & 59 & 7 & .77 & .55 & -4.8 & 1.5 & 5.8 & \\
\hline $1,039.3$ & $-1,200$ & 240 & - & 70 & 0 & 2.68 & 56 & 6 & .79 & .56 & -.73 & -.8 & 3.6 & \\
\hline $1,055.2$ & $-1,200$ & 40 & 16.8 & 70 & -1 & 2.69 & 55 & 5 & .79 & .56 & -8.1 & -1.5 & 2.9 & \\
\hline $1,061.3$ & -_- 90 & 70 & - & 125 & -4 & 2.74 & 67 & 14 & .70 & .49 & 1.6 & 7.6 & 11.6 & \\
\hline $1,079.2$ & --- & 120 & 16.8 & 80 & 3 & 2.63 & 63 & 7.5 & .77 & .57 & -1.6 & 4.5 & 8.7 & \\
\hline $1,109.1$ & --- & 160 & 16.5 & 70 & 3 & 2.63 & 61 & 7 & .78 & .59 & -3.2 & 3.0 & 7.2 & \\
\hline $1,115.5$ & 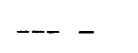 & 105 & 16.5 & 135 & -3 & 2.72 & 66 & 12 & .72 & .51 & -.8 & 6.8 & 10.1 & Shale? \\
\hline $1,125.3$ & $-\cdots$ & 100 & 16.5 & 175 & -3 & 2.72 & 72 & 16 & .68 & .49 & -5.6 & 11.4 & 15.2 & \\
\hline $1,130.8$ & --- & 300 & 16.3 & - & 4.5 & 2.60 & 63 & 5.5 & .79 & .59 & -1.6 & 4.5 & 8.7 & Cycle skip. \\
\hline
\end{tabular}


ment. Greatest loss of energy occurs when the neutrons collide with particles of similar mass, such as hydrogen. These particles having reduced energy are called thermal neutrons. The neutron tool is generally designed to count either thermal neutrons or the gamma radiation resulting from neutron capture by hydrogen (Schlumberger, Ltd., 1972b). The recorded porosity must be corrected for gases, lithologies other than limestone, and fluids other than water.

In clean (nonshaly) formations, the neutron log is a measure of liquid-filled porosity. For shaly formations and for minerals such as gypsum $\left(\mathrm{CaSO}_{4} \cdot 2 \mathrm{H}_{2} \mathrm{O}\right)$, the indicated porosity is in error because the logging tool also measures the hydrogen associated with bound water and crystallization water. The neutron-porosity $\log$ in plate 1 is scaled linearly in percent porosity. The tool is designed to calculate a porosity from a signal that would result if the rock were limestone that contained water (Schlumberger, Ltd., 1972b).

Uncorrected apparent limestone porosity $(\phi n)$ is presented in table 2 (col. 9). Care was taken to select porosity values from the neutron log opposite points in the borehole where the caliper log indicated the hole was reasonably smooth. Much of the shift toward higher apparent porosities in zones, such as those at depth intervals from 305 to $355 \mathrm{~m}, 445$ to $449 \mathrm{~m}$, and 796 to $826 \mathrm{~m}$, is due to formation shaliness. Most porosity spikes were caused by poor contact between the logging tool and the borehole wall, opposite fractures and washouts. However, spikes indicating high porosity at depths of 181,201 , and $274 \mathrm{~m}$ occur opposite evaporaterich beds. There is a slight but overall decrease in minimum porosity with depth. The lowest porosity value, however, occurs at depths of $610 \mathrm{~m}$ in a dense, 1.8-m-thick bed that appears, from cuttings, to be cherty and quartzose. Minimum neutron porosities average 4 percent in sandstones that are thought to have no porosity. This apparent discrepancy is probably caused by the increased clay content of some sandstones. Porous zones that are greater than $5 \mathrm{~m}$ thick at depths greater than $150 \mathrm{~m}$ occur throughout the well (table 3). Table 4 shows data for selected intervals in the Sears No. 1 well.

\section{SONIC LOG}

Because sonic-log response is dependent on porosity and is independent of fluid content for lower porosities, it is an excellent means of estimating porosity. Shaliness tends to increase interval traveltime from sonic $\log (\Delta t)$ because the characteristic velocity of shale matrix is slower than that of sandstone. Thus, porosities calculated for shaly sandstones on the basis of a clean
TABLE 3.-Porous zones (greater than $5 \mathrm{~m}$ thick) below 150-m depth in the Sears No. 1 well, North Carolina

\begin{tabular}{|c|c|c|c|}
\hline \multicolumn{4}{|c|}{ [Analysis of gamma-ray, density, neutron, and sonic logs] } \\
\hline $\begin{array}{l}\text { Depth to } \\
\text { top of } \\
\text { zone } \\
\text { (m) }\end{array}$ & $\begin{array}{l}\text { Approximate } \\
\text { thickness } \\
\text { of zone } \\
\text { (m) }\end{array}$ & $\begin{array}{l}\text { Average } \\
\text { effective } \\
\text { porosity } \\
\text { (percent) }\end{array}$ & $\begin{array}{c}\text { Average } \\
\text { bulk density } \\
\left(\mathrm{g} / \mathrm{cm}^{3}\right)\end{array}$ \\
\hline 189 & 9 & 11.40 & 2.66 \\
\hline & 18 & 8.49 & 2.66 \\
\hline 341 & 12 & 6.83 & 2.67 \\
\hline 391 & 8 & 7.86 & 2.67 \\
\hline 434 & 9 & 6.70 & 2.67 \\
\hline 497. & 18 & 5.27 & 2.67 \\
\hline 565 & 6 & 5.29 & 2.67 \\
\hline $622-$ & 18 & 4.46 & 2.69 \\
\hline & 12 & 33.66 & 2.70 \\
\hline $826^{4}-$ & 21 & 2.92 & 2.70 \\
\hline $933^{4} \ldots$ & 15 & 1.86 & 2.71 \\
\hline
\end{tabular}

${ }^{1}$ Average porosity is clay-free porosity.

${ }^{2}$ Higher density zones indicate an increase of clay with sandstone matrix at depth.

${ }^{3}$ Lower porosities result from compaction.
'Porosities below 4 percent are effectively zero for sandstones.

TABLE 4.-Rock characteristics processed from logs for the Sears No. 1 well, North Carolina

\begin{tabular}{|c|c|c|c|c|c|c|}
\hline $\begin{array}{c}\text { Depth } \\
\text { (m) }\end{array}$ & & $\begin{array}{c}\text { Water } \\
\text { saturation } \\
\text { (percent) }\end{array}$ & $\begin{array}{c}\text { Total } \\
\text { porosity } \\
\text { (percent) }\end{array}$ & $\begin{array}{c}\text { Secondary } \\
\text { porosity } \\
\text { (percent) }\end{array}$ & $\begin{array}{c}\text { Shale } \\
\text { content } \\
\text { (percent) }\end{array}$ & $\begin{array}{c}\text { Matrix } \\
\text { bulk } \\
\text { density } \\
\left(\mathrm{g} / \mathrm{cm}^{3}\right)\end{array}$ \\
\hline 153 & --- - - & 100 & 7.8 & - & 39 & 2.66 \\
\hline 167 & -_- & 100 & 1.6 & - & 46 & 2.80 \\
\hline 184 & - & 100 & 9.3 & - & 28 & 2.66 \\
\hline 198 & 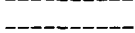 & 100 & 10.7 & - & 17 & 2.66 \\
\hline 214 & - & 100 & 0 & - & 44 & 2.66 \\
\hline 229 & -1 & 100 & 12.9 & - & 0 & 2.66 \\
\hline 249 & 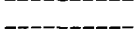 & 100 & 7.5 & - & 26 & 2.67 \\
\hline 259 & - & 100 & 10.6 & - & 0 & 2.65 \\
\hline 275 & - & 100 & 7.2 & - & 44 & 2.65 \\
\hline 290 & - & 100 & 10.8 & - & 17 & 2.66 \\
\hline 306 & - & 100 & 9.5 & - & 26 & 2.66 \\
\hline 322 & - & 100 & 3.2 & - & 41 & 2.80 \\
\hline 336 & - & 100 & 2 & - & 47 & 2.80 \\
\hline 351 & - & 100 & 9.7 & - & 0 & 2.66 \\
\hline 367 & - & 100 & 4.8 & - & 40 & 2.66 \\
\hline 381 & - & 100 & 0 & - & 49 & 2.77 \\
\hline 396 & - & 100 & 8.6 & - & 3 & 2.67 \\
\hline 412 & - & 100 & .9 & - & 41 & 2.65 \\
\hline 428 & - & 100 & 3.4 & - & 29 & 2.67 \\
\hline 442 & -1 & 100 & 6.1 & - & 16 & 2.67 \\
\hline 472 & - & 100 & 0 & - & 47 & 2.65 \\
\hline 489 & 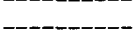 & 100 & 11 & - & 3 & 2.67 \\
\hline 526 & - & 100 & 1.1 & 0.3 & 39 & 2.65 \\
\hline 550 & - & 100 & 6.9 & .5 & 13 & 2.66 \\
\hline 580 & - & 100 & 6.3 & - & 7 & 2.69 \\
\hline 617 & - & 100 & 8 & - & 0 & 2.67 \\
\hline 762 & - & 100 & 1.3 & - & 37 & 2.72 \\
\hline 917 & - & 100 & 3.6 & - & 37 & 2.69 \\
\hline 1,067 & - & 100 & 7.2 & - & 3 & 2.71 \\
\hline 1,129 & - & 100 & 4.4 & - & 1 & 2.72 \\
\hline
\end{tabular}

sandstone-matrix velocity tend to yield porosity values that are high.

The speed of sound in rock is determined principally by the lithology and porosity of the rock. Indurated sandstone, limestone, and dolomite have high compressional sonic velocities. Salt, gas, and water have relatively low velocities. The sonic $\log$ on plate 1 is a record- 
TABLE 5.-Sonic velocities and traveltimes for common materials and rocks of the Durham Triassic basin

[Modified from Gerhart-Owens, Inc., 1974.- means no value given]

\begin{tabular}{lrrrr}
\hline & $\begin{array}{c}\text { Matrix } \\
\text { velocity } \\
(\mathrm{km} / \mathrm{s})\end{array}$ & $\begin{array}{c}\text { Matrix } \\
\text { velocity } \\
(\mathrm{ft} / \mathrm{s})\end{array}$ & $\begin{array}{c}\text { Interval } \\
\text { travel- } \\
\text { time } \\
(\mu \mathrm{s} / \mathrm{ft})\end{array}$ & $\begin{array}{c}\text { Interval } \\
\text { travel- } \\
\text { time } \\
(\mu \mathrm{s} / \mathrm{m})\end{array}$ \\
\hline Sandstones & $5.49-5.9$ & $18,000-19,500$ & $55.5-51.0$ & $182.1-167.3$ \\
Limestones -- & $6.4-7.0$ & $21,000-23,000$ & $47.6-43.5$ & $156.2-175.5$ \\
Dolomites -- & 7.0 & 23,000 & 43.5 & 147.7 \\
Anhydrite - & 6.1 & 20,000 & 50.0 & 164.0 \\
Salt & 4.6 & 15,000 & 66.7 & 218.8 \\
Shale & $1.8-4.9$ & $6,000-16,000$ & - & $-\overline{1}$ \\
Water & 1.6 & $5,000-5,300$ & 189.0 & 620.1 \\
Oil - & 1.3 & 4,300 & 238.0 & 780.8 \\
\hline
\end{tabular}

ing of a compressional wave's traveltime through the rock parallel to the wellbore. The log is recorded in microseconds per foot $(\mu \mathrm{s} / \mathrm{ft})$, which is the reciprocal of the compressional wave velocity; this value is called the interval traveltime $(\Delta t)$. Values of traveltimes for common rock types and fluids in the Durham Triassic basin are presented in table 5 .

The sonic-logging tool has two transmitters that are pulsed alternatively. The received signals are integrated over time to give the recorded interval traveltime and integrated traveltime. The traveltime between any two depths in the hole may be computed by adding each millisecond pulse (indicated by tick marks) between the desired depths.

The first signal arriving at the sonic receiver is generally the compressional wave that has traveled through the rock adjacent to the borehole. However, if that signal is attenuated by gas, salt, or fractures in the formations, the receiver will record some altered arrival time. The result is a large displacement of the log curve to the left toward lower velocities (higher $\Delta t$ ) called "cycle skipping." In the Sears No. 1 well, a caliper (borehole-diameter) log indicates that this phenomenon occurs opposite enlarged parts of the wellbore.

Below a depth of $848 \mathrm{~m}$, the sonic log has several sharp spikes or deflections to the right. Although these spikes could represent thin-bedded anhydrite zones having high velocity, the recorded traveltime is shorter than normal for anhydrite; therefore, these spikes are assumed to be noise spikes caused by cable and tool noise triggering the sonic receiver in a low-signal area of the borehole.

The sonic log, which is matrix-velocity dependent, is a good tool for determining lithology and is commonly used for correlation purposes. The overall character of the Sears No. 1 sonic log confirms the cyclic character of the sedimentary rocks and correlation of the 793-mdepth to 1,134-m-depth interval with the 1,174-m-depth to 1,524-m-depth interval of the Groce No. 1 well (pl. 1).
Wyllie and others $(1956,1958)$ and Wyllie (1963) have developed a formula that can be used to calculate porosity from interval traveltime for shale-free sandstone:

$$
\text { porosity of sandstone }=\frac{\Delta t-\Delta t_{m a}}{\Delta t_{f}-\Delta t_{m a}}
$$

where:

$$
\begin{aligned}
\Delta t= & \text { the interval traveltime from the sonic log } \\
& (\mu \mathrm{s} / \mathrm{ft}) ; \\
\Delta t_{m a}= & \text { the interval traveltime for the rock matrix } \\
& (\mu \mathrm{s} / \mathrm{ft}) ; \text { and } \\
\Delta t_{f}= & \text { the interval traveltime from the sonic log for } \\
& \text { fluid }(\mu \mathrm{s} / \mathrm{ft}) .
\end{aligned}
$$

Porosities were calculated from the sonic log by the Wyllie formula for selected intervals of the Sears No. 1 well and are presented in table 2. The accuracy of these calculated porosities depends on the accuracy of estimated matrix velocity obtained from the sonic log. An error difference of $1.0 \mu \mathrm{s} / \mathrm{ft}$ changes the calculated porosity about 0.5 percent.

Crossplots showing the relation of sonic velocity to bulk density, sonic velocity to neutron porosity, and bulk density to apparent limestone porosity were constructed from logs (figs. 3-5) to investigate the lithologic properties of layers in the Sears No. 1 well. The major portion of the points in figures 3-5 are plotted in the limestone-sandstone range, with matrix sonic velocities from $5.5 \mathrm{~km} / \mathrm{s}$ to $6.4 \mathrm{~km} / \mathrm{s}\left(\Delta t_{m a}=55.5\right.$ to $47.6 \mu \mathrm{s} / \mathrm{ft}$ ). Most of the points on the density-sonic velocity crossplot are plotted in the dolomite range. The rocks associated with these points are identified as mudstones and argillites. The displacement of data points into the dolomite region of figure 3 is not the result of their having a dolomite matrix, but rather a result of high density-low matrix sonic velocity (higher $\left.\Delta t_{m a}\right)$. The measured high densities also indicate that the shales penetrated in the Sears No. 1 well do not have anomalous high-hydrostatic pressure or overpressure. Overpressured shales tend to be less compacted and have higher porosity and lower density.

\section{GAMMA-RAY LOG}

The gamma-ray log is a measure of the natural emission of gamma-ray particles from decay of radioactive minerals in rocks around the borehole. ${ }^{3}$ Measurement

${ }^{3}$ The American Petroleum Institute uses a standard calibration test pit to measure certain log parameters such as gamma-ray emission and porosity. API units are standard geophysical industry measures. 


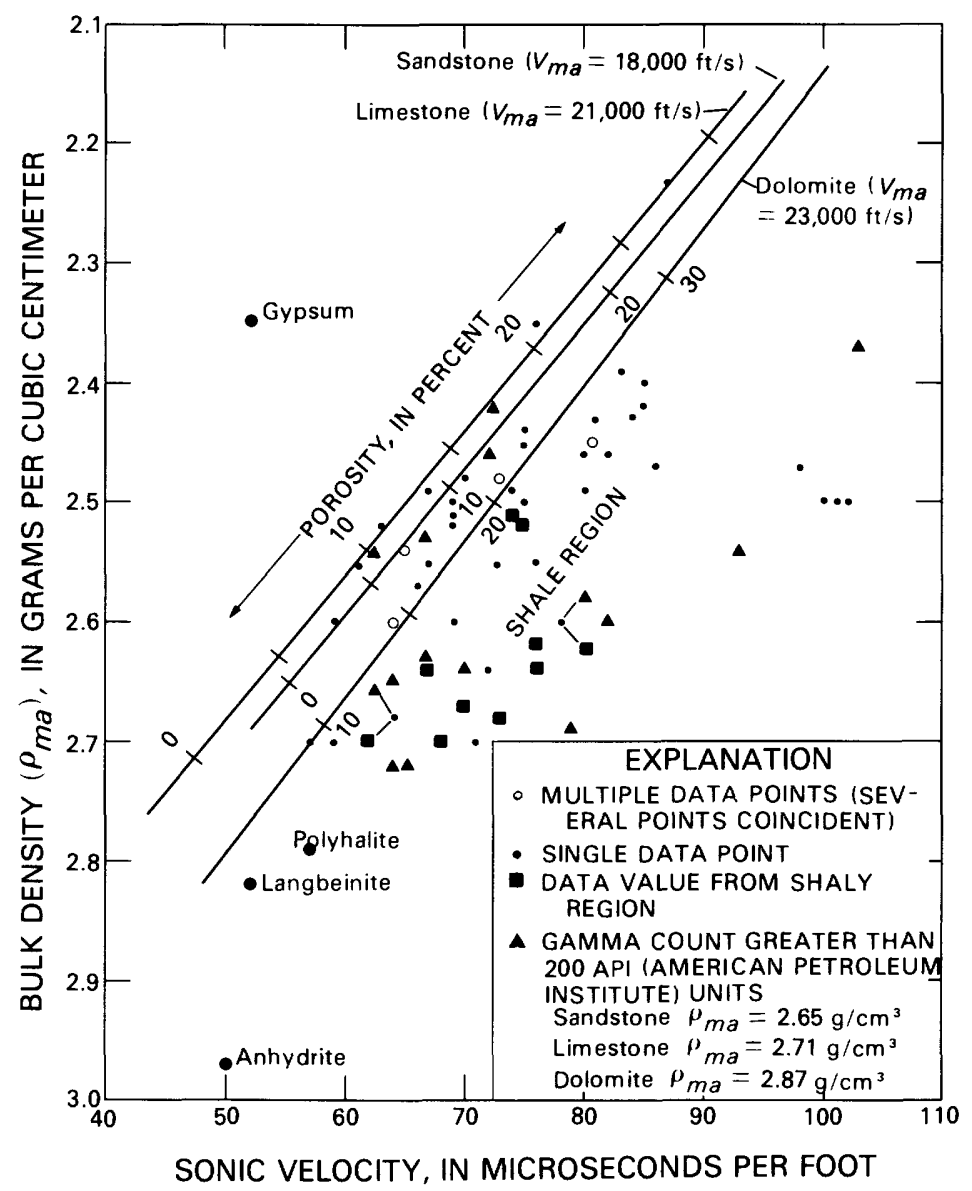

Figure 3. - Relation of bulk density to sonic velocity for rocks in the Sears No. 1 well, North Carolina (from Bain and Brown, 1981). Sonic log was recorded in $\mu \mathrm{s} / \mathrm{ft}$, or interval traveltime, which is the reciprocal of matrix sonic velocity $\left(V_{m}\right)$, recorded in $\mathrm{ft} / \mathrm{s}$. See table 5 for correlation. Points not plotted on solid lines represent rocks composed of more than one lithologic type.

is generally made with a borehole scintillation counter and recorded in American Petroleum Institute (API) units (Wyllie, 1963, p. 118), as in plate 1 . Gamma-ray radiation is random; therefore, a time constant and logging speed are chosen to give a good average measurement. One API gamma-ray unit is defined as $1 / 200$ of the difference between the deflections produced on a log by the radiation from two standard formations in a test pit in Houston (Wyllie, 1963).

The gamma-ray curve and the resistivity and sonic logs illustrate the alternating pattern of sandstone and shale in the Sears No. 1 well. The cleaner sandstones occur at depths of $289,351,537$, and $782 \mathrm{~m}$ and have radiation values of 50 to 55 API units. Most of the units identified on the sample log as sandstones have radiation levels of 60 to 80 API units. The $S P$ curve opposite the sandstone zones has a higher negative deflection, indicating that the rocks are filled with water and are more permeable. The lack of a good $S P$ deflection opposite the 782-m zone indicates that the zone's water chemistry is close to that of the drilling mud and (or) that this sandstone contains no water. The gamma-gamma density log indicates that the porosity of sandstone is less than or equal to 2 percent.

The shaly rocks in the Sears No. 1 well consist predominantly of massive argillite and mudstone. Small amounts of thinly laminated fissile shale are present in some cuttings. The radiation level of the gray, massive argillaceous unit between a depth of 308 and $338 \mathrm{~m}$ is a good example of the shale radiation level of the upper rock of the Sears No. 1 well. The red mudstone and argillite facies below a depth of $640 \mathrm{~m}$, however, has a lower radiation level about 100 API units.

The upper $610 \mathrm{~m}$ of this $\log$ has several anomalous gamma-ray peaks that have intensities of more than 200 API units. The largest of these intensities occurs at $420 \mathrm{~m}$.

The gamma-ray log anomalies at depths of 161,188 , $398,499,571$, and $585 \mathrm{~m}$ appear, from sample logs and $\log$ crossplots, to occur in sandstone that is shaly or radioactive. Some anomalies definitely occur at the base of the sandstones. The sandstone at $161 \mathrm{~m}$ is calcareous. 


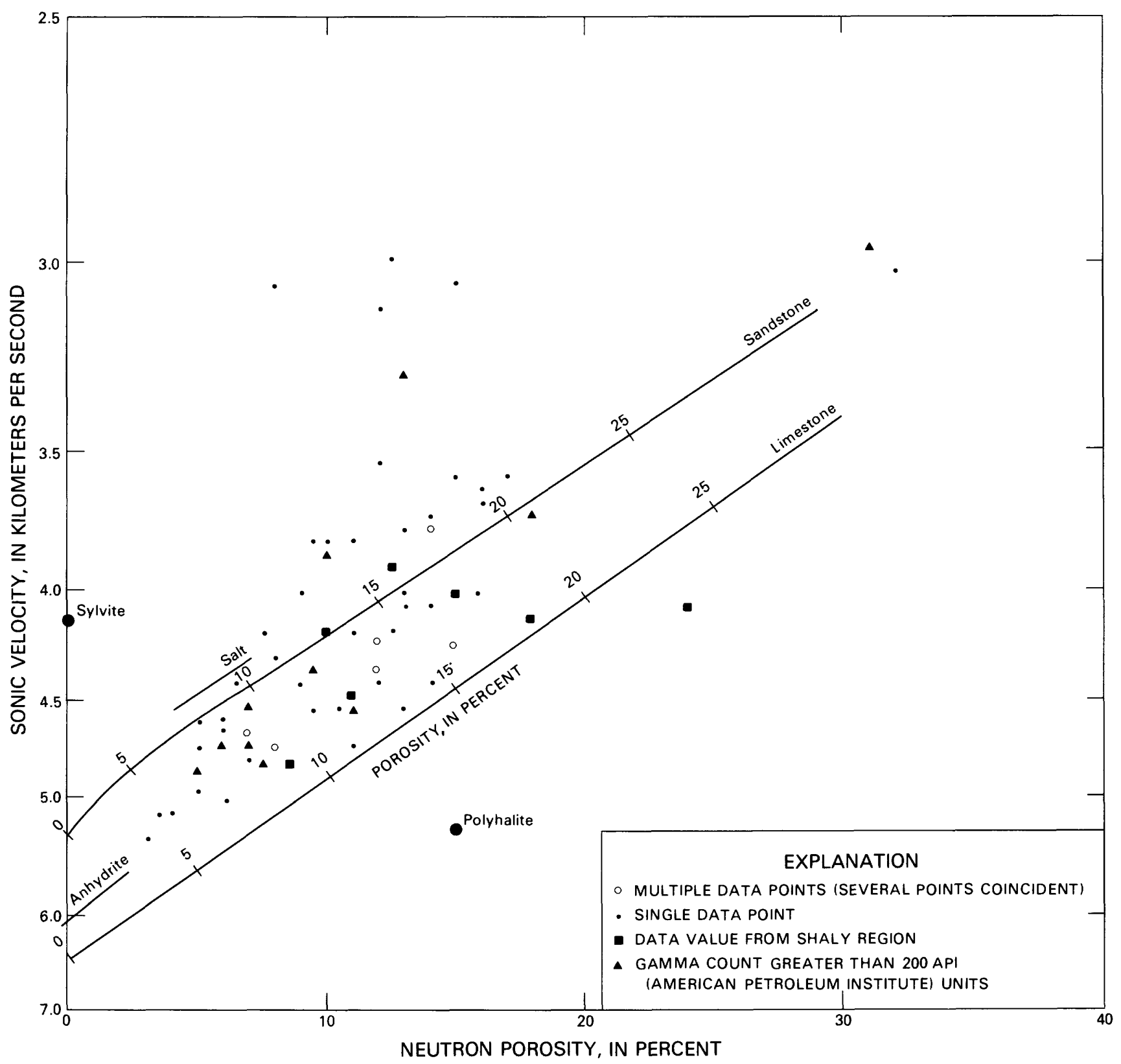

Figure 4. - Relation of neutron porosity to sonic velocity for Triassic rocks in the Sears No. 1 well, North Carolina (from Bain and Brown, 1981). Points plotted between solid lines represent rocks composed of more than one lithologic type.

Anomalies at depths of $181,271,418$, and $420 \mathrm{~m}$ correspond to shale. The anomaly at a depth of $201 \mathrm{~m}$ may correspond to siltstone. Some of the anomalies, such as at depths of 181 and $188 \mathrm{~m}$, correspond to washouts of the hole, which affect the gamma-ray readings.

\section{TEMPERATURE LOG}

A thermal gradient exists between the Earth's core and surface. The temperature near the surface generally increases about $1^{\circ} \mathrm{C}$ for every $55 \mathrm{~m}$ of depth. Departure from this average gradient is caused by differences in the thermal conductivity of rocks, the degree of water circulation, and the depth of magma.

Borehole-temperature logging is accomplished with a sonde having a thermistor whose internal resistance changes in response to temperature change. In addition to determining gross thermal gradients, the temperature $\log$ is used to detect inflow and outflow of liquids and gases in the borehole, thermal conductivity of indi- 


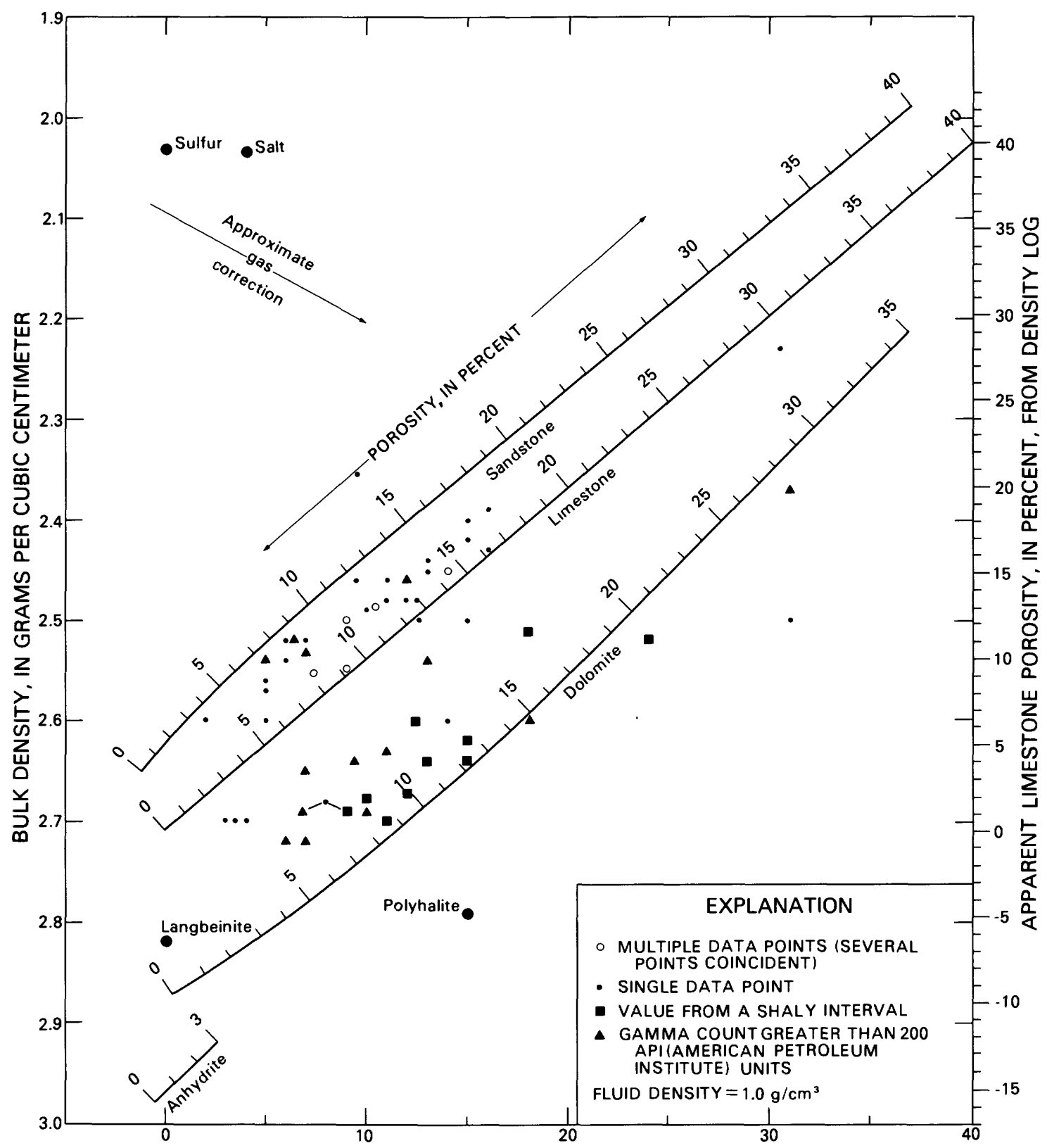

APPARENT LIMESTONE POROSITY (SIDEWALL NEUTRON POROSITY NEUTRON INDEX), IN PERCENT

FIGURE 5.- Relation of bulk density to apparent limestone porosity for rocks of the Sears No. 1 well, North Carolina (from Bain and Brown, 1981). Points between solid lines indicate mixtures of lithologic types.

vidual beds, and location of new cement grout behind casings.

The temperature log of the Sears No. 1 well is presented in plate 1 and figure 6 . The temperature log in figure 6 is plotted beside the caliper log and a log of drilling samples to facilitate interpretation of the temperature anomalies. The temperature gradient at the Sears No. 1 well is $1^{\circ} \mathrm{C} / 66 \mathrm{~m}$.

Most of the temperature anomalies in the Sears No. 1 well that occur above a 500-m depth appear to be caused by cooler water moving down the wellbore and outflow into more permeable sandstones. Most of the anomalies below $500 \mathrm{~m}$ appear opposite points identified on the caliper log as fractures. The relatively small temperature gradient of this well compared to that of the Groce No. 1 well may indicate deep circulation of ground water. Additional discussion of boreholetemperature logging is found in Keys and MacCary (1971). 


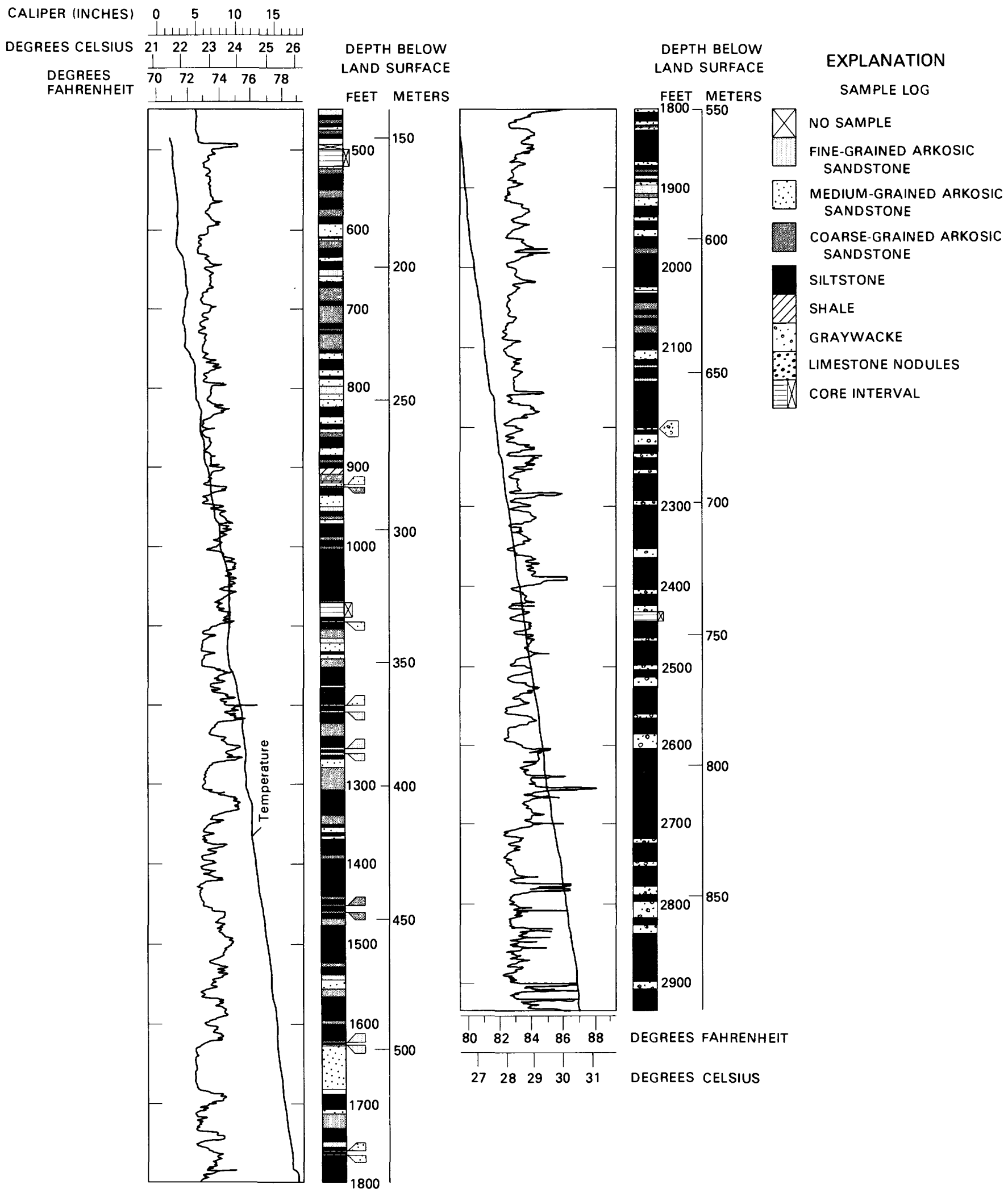

Figure 6. - Correlation of temperature log with caliper and drilling sample logs. 


\section{ACOUSTIC-TELEVIEWER LOG}

An acoustic televiewer was used to examine the detailed physical character of the Sears No. 1 well wall-rock in areas having temperature and caliper-width anomalies. The acoustic-televiewer log shows (1) areas of high reflectivity (light-colored areas on the log) that indicate dense layers and (2) areas of low reflectivity (dark-colored areas on the $\log$ ) that indicate fractures or openings in the rock. Bright areas on the log are a function of the reflected energy from the wellbore. The acoustic-televiewer tool spins or rotates from north to south as it is lowered into the borehole. Figure 7 illustrates the fractures and washouts observed between $590-\mathrm{m}$ to $620 \mathrm{-m}$ depth and $650-\mathrm{m}$ to $660-\mathrm{m}$ depth in the Sears No. 1 well. Vertical drill-bit marks and horizontal and dipping fractures (dark areas on $\log$ ) can be observed on the televiewer log. Most caliper and televiewer anomalies are coincident with temperature anomalies (Keys and others, 1979) for the Sears No. 1 well.

\section{APPLICATION OF LOG DATA}

\section{DETERMINATION OF LITHOLOGY}

The data from sonic, density, and neutron logs are sometimes crossplotted to give additional information on mineral composition of rocks. Figure 8 is a sonic-density crossplot of data for sandstones from the Sears No. 1 well. Figures 9 and 10 are $M-N$ parameter crossplots of the log data from the Sears No. 1 well.

Equations for $M$ and $N$, from Schlumberger, Ltd. (1972), are

$$
M=\frac{\Delta t_{f}-\Delta t}{\varrho b-\varrho f} \times 0.01
$$

and

$$
N=\frac{\phi n_{f}-\phi n}{\varrho b-\varrho f}
$$

where

$\Delta t_{f}=$ interval traveltime from sonic $\log$ for fluid $(189 \mu \mathrm{s} / \mathrm{ft}$ for fresh mud and $185 \mu \mathrm{s} / \mathrm{ft}$ for salt mud);

$\Delta t=$ interval traveltime from sonic logs, in $\mu \mathrm{s} / \mathrm{ft}$;

$\varrho b=$ bulk density of logged interval;

$\varrho f=$ density of fluid (1.0 for fresh mud and 1.1 for salt mud);

$\phi n_{f}=$ neutron-log porosity for fluid (use 1.0);

$\phi n=$ percentage neutron porosity of logged interval from compensated neutron or sidewall neutronporosity log;

$0.01=$ multiplication factor;

$M=$ lithology-dependent quantity derived by using density- and sonic-log values; and

$N=$ lithology-dependent quantity derived by using density- and neutron-log values.
The data points on figures 7 and 8 are a result of lithologydependent values, $M$ and $N$, in which the effects of the rock matrix are calculated if sonic-log values are divided by density-log values and neutron-log values are divided by density-log values. The value $M$ is derived by dividing the porosity component (interval traveltime difference) of the sonic log by the porosity component (density-value difference) of the density log. The value $N$ is derived by dividing the porosity component (neutron-value difference) of the neutron log by the porosity component (density-value difference) of the density log (Schlumberger, Ltd., 1972, p. 73). Because the porosities determined from the logs are different, the calculations are characteristic of the matrix effects measured by the logging instruments. The multiplication factor $0.01 \mathrm{ap}-$ plied in determining the value $M$ makes $M$ and $N$ of the same order of magnitude.

Because the position of plotted points depends on mineralogy, the binary mineralogy mixtures under ideal conditions should plot along lines connecting any two minerals, and trinary mineralogy mixtures should plot in the triangular areas connecting the respective end points. The presence of gas or evaporite rocks in the well causes a shift in the plot of data values to the upper right, and shaliness causes a shift in the plot of data values to the graph's lower center. Figure 8 indicates that the upper $640 \mathrm{~m}$ of the Sears No. 1 well contains some quartz, calcite, and anhydrite. Other data points are closer to the shale region on the graph, indicating the rocks are shaly in this interval. This interpretation agrees with the sample data shown in plate 1 .

\section{DETERMINATION OF SECONDARY POROSITY}

Normally, the porosity determined from a neutron-sonic velocity crossplot and from a neutron-density crossplot differs; this difference reflects secondary porosity, which tends to shift a point upwards on $M-N$ plots (figs. 9 and 10 ). This relation is caused by the tendency of the sonicvelocity signal to overlook or skip over larger openings in the rock and to record only intergranular porosity. Neutron- and density-logging tools respond to total porosity, regardless of porosity type. However, a sonic log tends to ignore vugs, because the sound energy is propagated through the surrounding matrix and bypasses the vugs. Therefore, a sonic log used in conjunction with a density and (or) neutron log can provide an estimate of the secondary porosity, as well as intergranular porosity, of a formation of known lithology (Schlumberger, Ltd., 1972, p. 6). The effects of secondary porosity are small or neglible, as shown on figures 9 and 10.

\section{CORRELATION OF STRATIGRAPHIC UNITS IN BASIN}

Log data from the Sears No. 1 well and from the Groce No. 1 well (location shown on fig. 11) were compared 


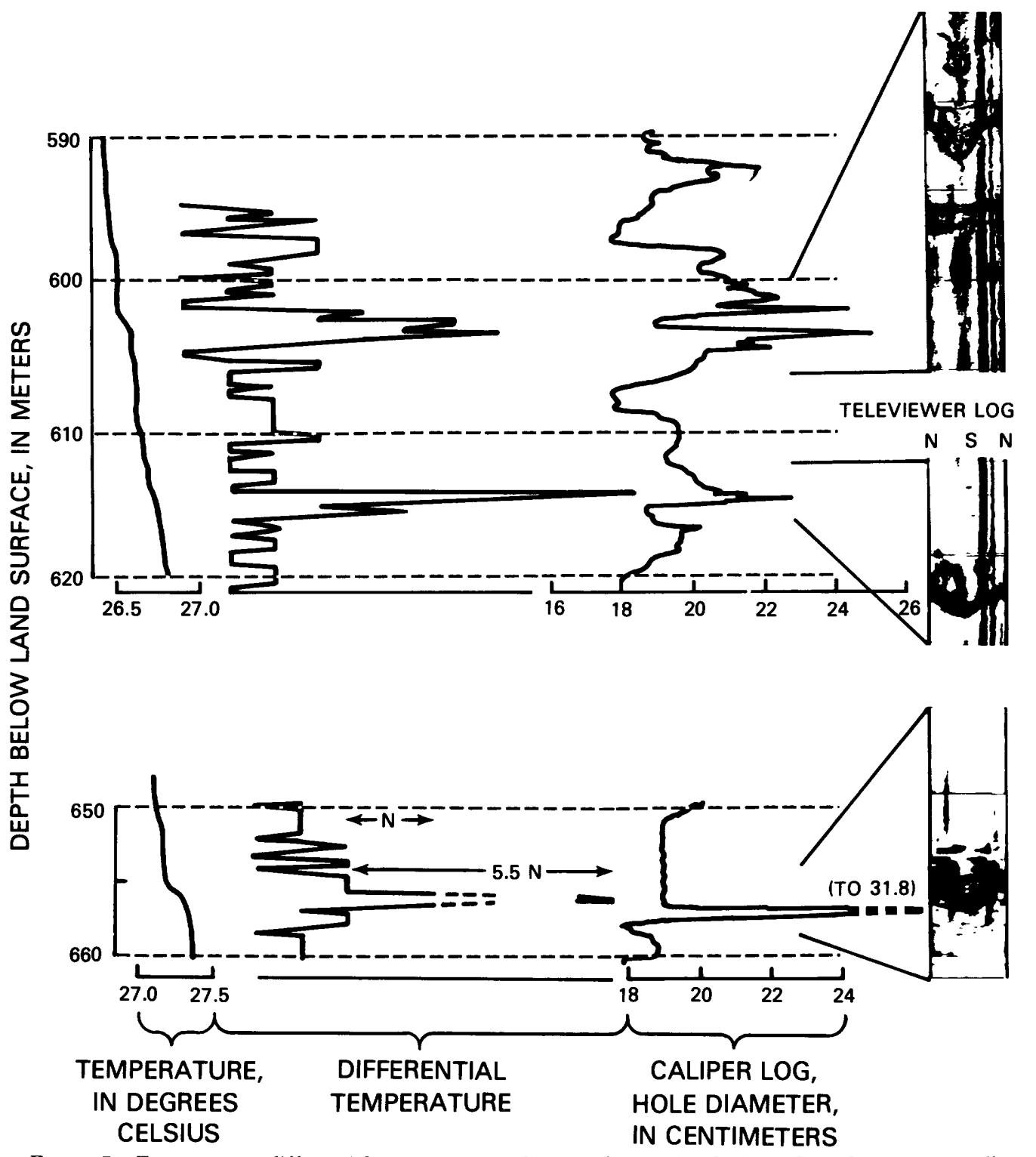

Figure 7.-Temperature, differential temperature, caliper, and acoustic-televiewer logs, Sears No. 1 well,

North Carolina (Keys and others, 1979).

to show how log data could be used to define stratigraphic relationships between two areas of the basin (pl. 1). The bottom $350 \mathrm{~m}$ of the Sears No. 1 well correlates with the bottom $396 \mathrm{~m}$ of the Pekin Formation in the Groce No. 1 well of the Sanford area on the basis of similar response in the dual induction-laterologs of the two wells (pl. 1). These logs suggest that as much as $590 \mathrm{~m}$ of the bottom part of the Sears No. 1 well may correlate with the bottom $640 \mathrm{~m}$ of the Groce No. 1 well. There is no indication of the presence of a unit in the Sears No. 1 well that is equivalent to the carbonaceous, coal- and oil-shale-bearing Cumnock Formation or to the Sanford Formation of the Groce No. 1 well. The stratigraphic relations between the two wells suggest that the environments of deposition were similar in both the Durham and Sanford areas during Pekin time and possibly into early Cumnock time (Bain and Brown, 1981). Thereafter, a stable, swampy, reducing environment having a slow rate of sediment accumulation prevailed in the Sanford area, while a higher energy environment was creating channel sands and point bars in the fine-grained alluvial-fan deposits in the New Hill area. In the Sanford area, the paludal deposits were succeeded by reddish, poorly sorted, detrital materials. In the New Hill area, a different source area contributed increasingly greater amounts of gray to buff detrital granitic material to the sediment being deposited (Bain and Brown, 1981, fig. 3). 


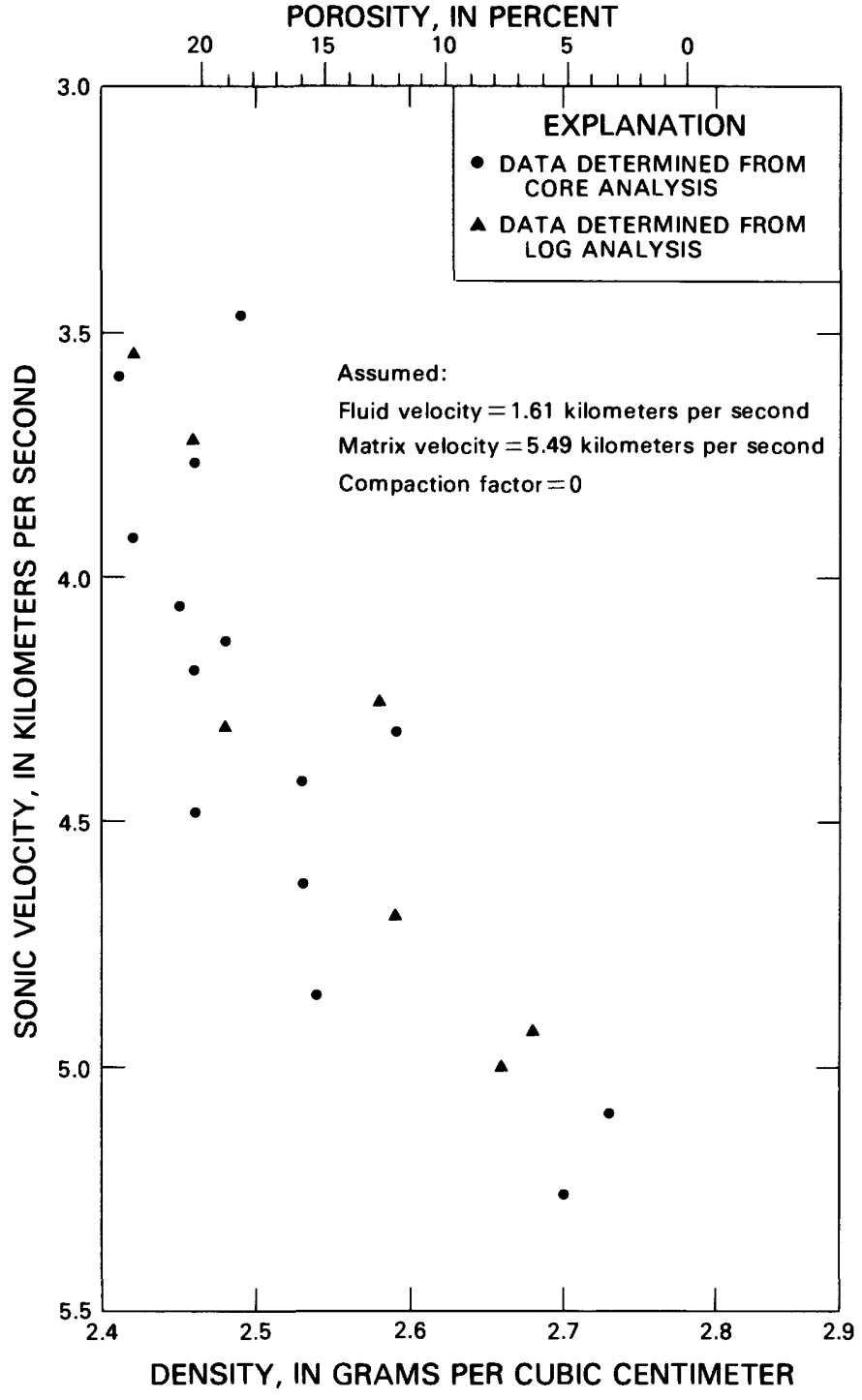

Figure 8. - Relation of density to sonic velocity of cores of selected sandstone intervals.

\section{DETERMINATION OF ROCK PROPERTIES BY PHYSICAL-TESTING TECHNIQUES}

The Triassic rocks of the Durham Triassic basin have low porosity and permeability because they were deposited as continental sediments; therefore, the rocks are poorly sorted. Much of the initial or primary porosity has been lost through compaction, lithification, and diagenesis. Consequently, ground-water yields are lowgenerally less than $2.6 \mathrm{~L} / \mathrm{s}$ in shallow domestic wells (Bain and Thomas, 1966). Laboratory testing determined porosity, permeability, bulk density, moisture content, sonic velocity, resistivity, and mechanical strength.

Results of physical tests of representative core samples from the Sears No. 1 test well and of core samples from the Deep River coal study (Reinemund, 1955) in the

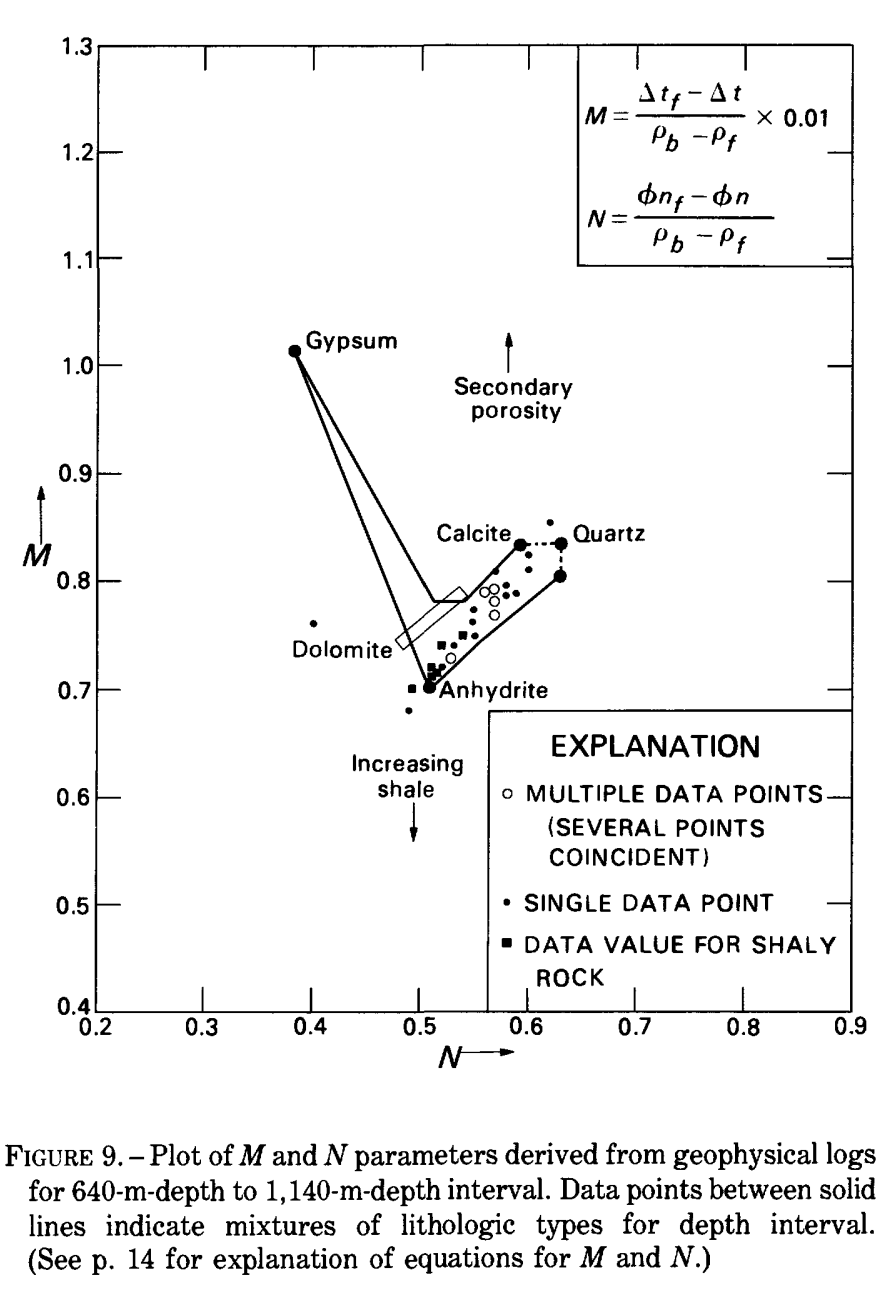

Sanford area are summarized in tables 6 and 7, respectively. The following sections describe the test procedures performed on Sears No. 1 well cores by Terra Tek, Inc., of Salt Lake City, Utah (written commun., 1976).

\section{BULK DENSITY, MOISTURE CONTENT, AND EFFECTIVE POROSITY}

Physical-properties tests were performed to determine the bulk density, moisture content, and effective porosity of each core sample. Samples for the physical-property tests were obtained by breaking two fragments of approximately $30 \mathrm{~cm}^{3}$ each from a core. The bulk-density measurements were made by using a Ruska Mercury Porometer, which determines volume by mercury displacement. The densities obtained by this method are accurate to $\pm 0.005 \mathrm{~g} / \mathrm{cm}^{3}$.

The moisture content is expressed as a percentage of the wet weight and is determined by measuring the weight loss of a crushed sample during oven drying for 24 hours at $105^{\circ} \mathrm{C}$. The accuracy of this method is 0.1 percent. 


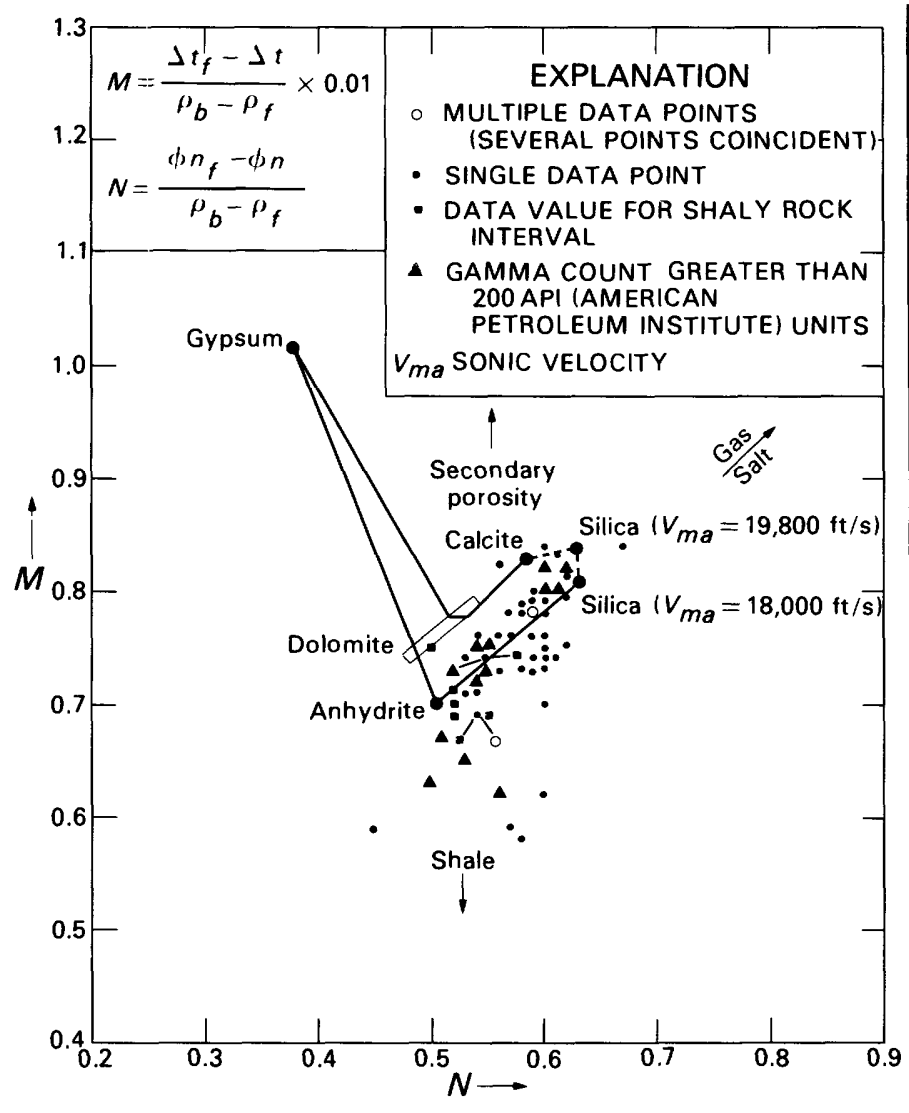

Figure 10. - Plot of $M$ and $N$ parameters derived from geophysical logs for 152-m-depth to 640-m-depth interval. Data points between solid lines indicate mixtures of lithologic types for depth interval. $V_{m a}$, matrix sonic velocity. (See p. 14 for explanation of equations for $M$ and $N$.)

The effective-porosity determinations were made by using a Beckman Gas Pycnometer. The effective porosity is essentially a measure of the connected pore volume. The Beckman technique uses helium gas to impregnate the sample and to measure the volume of the connected pores. The bulk volume is then determined by sealing the sample surface and determining the total volume of the sample. With this technique, measurements of effective porosity are accurate to \pm 0.05 percent.

The samples that were analyzed contain very little moisture. The largest moisture content measured was 1.1 percent in a sample from a depth of $745 \mathrm{~m}$. The effective porosities measured were relatively low; the largest porosity observed was 6.2 percent for the sample from a 745-m depth. Samples from 744-m and 1,141-m depths had effective porosities of less than 1 percent.

\section{PERMEABILITY}

Permeability was measured on cylindrical samples $2.54 \pm 0.013 \mathrm{~cm}$ in diameter and $0.635 \pm 0.051 \mathrm{~cm}$ in length. The test cylinders were sealed and confined at a confining pressure equal to $4.73 \times 10^{4} \mathrm{~g} / \mathrm{cm}^{2}$ per centimeter of depth. A pore pressure equal to 50 percent of the confining pressure was then established at each end of the sample. These pressures were maintained for a period of 4 hours to allow the pore pressure to stabilize. At the end of this period, the two ends of the sample were isolated from one another, and a pressure step of approximately $4.62 \mathrm{~g} / \mathrm{cm}^{2}$ was applied to one end of the sample. The differential pressure change across the sample was monitored over a period of approximately 15 hours. This differential pressure change allowed time for the system to establish a uniform differential pressure-decay rate.

The pore and driving water were estimated to contain $500 \mathrm{mg} / \mathrm{L} T D S$. A value of $500 \mathrm{mg} / \mathrm{L}$ was considered to be a reasonable approximation of the reservoir water chemistry. ${ }^{4}$ The dissolved solids were primarily sodium chloride. Use of $500-\mathrm{mg} / \mathrm{L} T D S$ water solution should result in slightly higher permeabilities than when using pure water, because the sample permeated with pure water experiences more clay swelling and therefore lower permeability.

An upper limit for water permeability tests was established by an unconfined gas permeability test on the sample from $1,141-\mathrm{m}$ depth. A gas permeability of $9.9 \times 10^{-8} \mu \mathrm{m}^{2}$ was obtained.

The permeability-test results show agreement with the effective porosity measurements. The samples from a $157-\mathrm{m}$ depth had the highest permeability and also the largest effective porosity. Samples from $960-\mathrm{m}$ and 1,138-m depths had similar permeabilities and almost identical effective porosities. Samples from 744-m and 1,141-m depths had the lowest permeabilities and the lowest effective porosities.

The permeabilities obtained for the Sears No. 1 well by using water of $500 \mathrm{mg} / \mathrm{L} \mathrm{TDS}$ are listed in table 6.

\section{SONIC VELOCITY}

The technique used to measure the sonic velocities of the various stratigraphic intervals is best described as the "through transmission system." The system can determine small delay times to a high degree of accuracy (Terra Tek, Inc., written commun., 1976).

The frequency synthesizer used is extremely stable; signal error is 1 part in $10^{7}$. A signal that passes through the test sample is compared with a signal coming directly from the synthesizer. The delay experienced by the signal in passing through the sample is then determined by comparing waveforms on an oscilloscope. The path

${ }^{4}$ Reservoir chemistry was determined from a U.S. Geological Survey Central Laboratory water-quality analysis that accompanied sample cores (lab ID No. 131010; Record No. 39928). 
TABLE 6. - Physical properties of core samples from the Sears No. 1 well, North Carolina

\begin{tabular}{|c|c|c|c|c|c|c|c|c|c|c|c|c|}
\hline \multirow{2}{*}{\multicolumn{2}{|c|}{$\begin{array}{l}\text { Sample } \\
\text { depth } \\
\text { (m) }\end{array}$}} & \multirow{2}{*}{$\begin{array}{c}\text { Bulk } \\
\text { density } \\
\left(\mathrm{g} / \mathrm{cm}^{3}\right)\end{array}$} & \multirow{2}{*}{$\begin{array}{c}\text { Water } \\
\text { content } \\
\text { (percent) }\end{array}$} & \multirow{2}{*}{$\begin{array}{c}\text { Gas } \\
\text { porosity } \\
\text { (percent) }\end{array}$} & \multicolumn{2}{|c|}{$\begin{array}{c}\text { Permeability } \\
\left(\mu \mathrm{m}^{2}\right)\end{array}$} & \multicolumn{2}{|l|}{$\begin{array}{c}\text { Velocity } \\
(\mathrm{km} / \mathrm{s})\end{array}$} & \multirow{2}{*}{$\begin{array}{l}\text { Formation } \\
\text { resistivity } \\
(\Omega \mathrm{m})\end{array}$} & \multirow{2}{*}{$\begin{array}{l}\text { Formation } \\
\quad \text { factor } \\
\left(F=R_{o} / R_{w}\right)^{1}\end{array}$} & \multirow{2}{*}{$\begin{array}{l}\text { Unconfined } \\
\text { strength } \\
\left(\mathrm{kPa} \times 10^{4}\right)\end{array}$} & \multirow{2}{*}{ Lithology } \\
\hline & & & & & Liquid & Air & Longitudinal & Shear & & & & \\
\hline 154 & -- & $\left({ }^{2}\right)$ & -- & 5 & $4.55 \times 10^{-10}$ & $10^{-4}$ & -- & -- & ${ }^{3} 58$ & 42.74 & -- & Sandstone. \\
\hline 154 & - & -- & - & 2.3 & -- & - & 53.73 & - & - & - & - & Do. \\
\hline 157 & - & - & - & 8.9 & $2.18 \times 10^{-3}$ & $10^{-2}$ & - & - & 3422 & ${ }^{4} 24.1$ & - & Do. \\
\hline 157 & -- & - & - & 12 & -- & - & $5 \overline{3.82}$ & - & -- & - & - & Do. \\
\hline 329 & - & - & -- & 1.3 & - & - & ${ }^{5} 3.28$ & - & - & -- & - & $\begin{array}{l}\text { Gray } \\
\text { argillite. }\end{array}$ \\
\hline 329 & -- & -- & -- & -- & $\begin{array}{l}\text { Sample } \\
\text { failed. }\end{array}$ & $9.9 \times 10^{-6}$ & - & -- & -- & -- & - & Do. \\
\hline 330 & -- & - & - & 4.7 & $4.85 \times 10^{-9}$ & $1.98 \times 10^{-5}$ & -- & $\ldots$ & 380 & 43.64 & -- & Siltstone. \\
\hline 330 & - & - & -- & 2.2 & -- & $\ldots$ & -- & - & -- & -- & - & Do. \\
\hline 330 & - & -- & - & 2.8 & -- & - & $54 . \overline{26}$ & -- & - & -- & - & Do. \\
\hline 744 & -- & 2.65 & $\overline{0.6}$ & .9 & $1.98 \times 10^{-9}$ & - & 4.50 & $\overline{2.37}$ & $\overline{72}$ & 66.5 & 8.8 & Red \\
\hline 745 & -- & 2.60 & 1.1 & 6.2 & $1.7 \times 10^{-8}$ & - & 4.71 & 2.60 & 130 & 12 & 11.4 & $\begin{array}{l}\text { sand- } \\
\text { stone. }\end{array}$ \\
\hline 960 & -- & 2.65 & .5 & 2.8 & $4.95 \times 10^{-9}$ & -- & 5.14 & 3.04 & 1,060 & 696 & 13.9 & $\begin{array}{l}\text { Con- } \\
\text { glomer- } \\
\text { ates. }\end{array}$ \\
\hline 1,138 & -- & 2.66 & .1 & 2.5 & $6.93 \times 10^{-9}$ & - & 5.14 & 3.02 & 736 & ${ }^{6} 67$ & 11.1 & Do. \\
\hline 1,141 & - & 2.73 & .1 & .9 & $3.96 \times 10^{-9}$ & $9.9 \times 10^{-8}$ & 4.55 & 2.36 & 195 & ${ }^{6} 18$ & 12.2 & Graywacke. \\
\hline
\end{tabular}

TABLE 7.-Physical properties of core samples from the Deep River coal field, North Carolina

\begin{tabular}{|c|c|c|c|c|c|c|c|c|}
\hline $\begin{array}{l}\text { Well } \\
\text { No. }{ }^{1}\end{array}$ & - & $\begin{array}{l}\text { Specimen } \\
\text { No. }\end{array}$ & $\begin{array}{c}\text { Depth } \\
(\mathrm{m})\end{array}$ & $\begin{array}{l}\text { Specific } \\
\text { gravity } \\
\left(\mathrm{g} / \mathrm{cm}^{3}\right)\end{array}$ & $\begin{array}{c}\text { Bulk } \\
\text { density } \\
\left(\mathrm{g} / \mathrm{cm}^{3}\right)\end{array}$ & $\begin{array}{l}\text { Porosity } \\
\text { (percent) }\end{array}$ & $\begin{array}{l}\text { Permeability } \\
\left(\mu \mathrm{m}^{2}\right)\end{array}$ & $\begin{array}{c}\text { Tensile } \\
\text { strength } \\
\text { (kPa) }\end{array}$ \\
\hline \multirow{7}{*}{\multicolumn{2}{|c|}{ DH-2 }} & 1 & 290 & 2.64 & 2.58 & 2.04 & $4.9 \times 10^{-5}$ & 12,170 \\
\hline & & 2 & 324 & $\begin{array}{l}\text { Sample } \\
\text { broken. }\end{array}$ & -- & -- & - & - \\
\hline & & 3 & 434 & 2.62 & 2.53 & 3.35 & $4.0 \times 10^{-5}$ & (3) \\
\hline & & $\mathbf{4 A}$ & 443 & 2.65 & 2.62 & .88 & $3.0 \times 10^{-5}$ & 14,286 \\
\hline & & ${ }^{2} 4 \mathrm{~B}$ & -- & -- & -- & -- & -- & 17.596 \\
\hline & & 5 & 409 & $\left(\mathbf{3}^{\mathbf{3}}\right)$ & -- & - & -- & -- \\
\hline & & 6 & 53 & 2.65 & 2.37 & 10.7 & $4.3 \times 10^{-4}$ & 5,191 \\
\hline \multirow{2}{*}{\multicolumn{2}{|c|}{ BH-11 _-_- }} & 7 & 68 & 2.66 & 2.53 & 4.82 & $\left(^{3}\right)$ & 4,385 \\
\hline & & 8 & 75 & 2.68 & 2.49 & 7.11 & $4.3 \times 10^{-4}$ & 9,970 \\
\hline \multirow[t]{2}{*}{ BH-10 } & ---_- - - & 9 & 19 & 2.71 & 2.00 & 26.4 & $2.1 \times 10^{-3}$ & 4,999 \\
\hline & & 10 & 32 & 2.71 & 2.49 & 8.00 & $9.9 \times 10^{-5}$ & 7,502 \\
\hline \multirow[t]{2}{*}{ BH-7 } & - - & $11 \mathrm{~A}$ & 352 & 2.66 & 2.64 & .83 & $2.0 \times 10^{-5}$ & 12,549 \\
\hline & & ${ }^{2} 11 B$ & - & -- & - & -- & -- & 9,998 \\
\hline BH-9 & ------ - - - & ${ }^{4} 12$ & 145 & 2.68 & 2.37 & 11.8 & $5.9 \times 10^{-4}$ & 5,440 \\
\hline
\end{tabular}

'Refer to Reinemund, 1955, for well locations.

${ }^{2}$ Duplicate tested tensile strength only.

${ }^{3}$ Specimen unable to be extracted from core.

'Oil saturation 3.25 percent.

length divided by the elapsed time of the signal passing through the sample gives the resulting acoustic velocity for that medium. The longitudinal wave is designated the " $P$ wave," and the shear wave is designated the "S wave."

The samples for sonic testing were $2.54 \pm 0.013 \mathrm{~cm}$ in diameter and $2.54 \pm 0.05 \mathrm{~cm}$ in length. Prior to testing, all test samples were saturated in an aqueous solution of $500 \mathrm{mg} / \mathrm{L} T D S$ (see footnote 4, in the Permeability section).

The samples were then confined at a pressure equal to $4.73 \times 10^{-4} \mathrm{~g} / \mathrm{cm}^{2}$ per centimeter of burial. P-wave and S-wave velocities for each depth interval were obtained. These velocities are accurate to \pm 1 percent. 


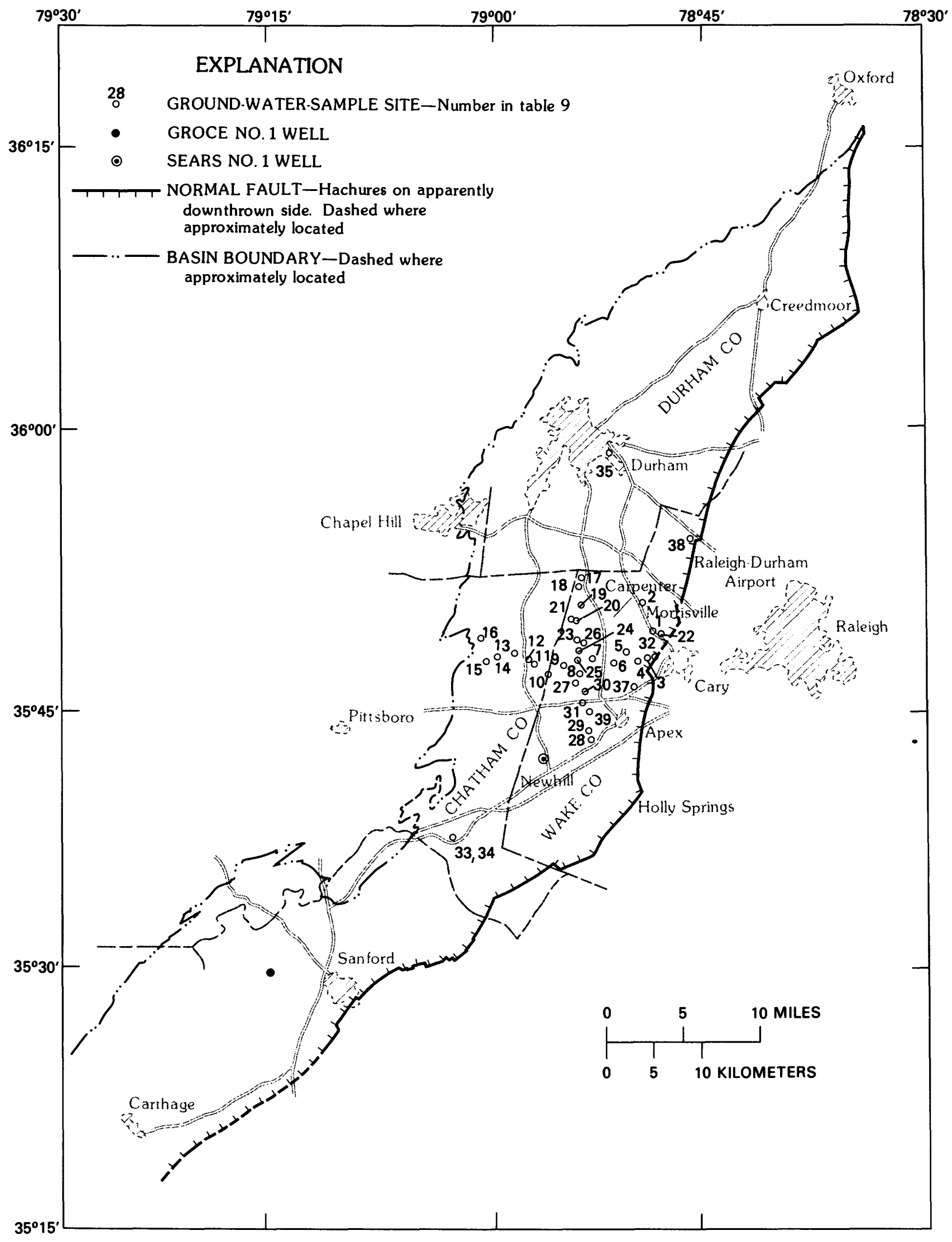

Figure 11.-Ground-water-sample site locations in Durham Triassic basin and Sears No. 1 well and Groce No. 1 well locations, North Carolina. 
Samples from $960-\mathrm{m}$ and 1,138-m depths that appeared to be composed of similar materials had virtually identical sonic velocities. A summary of the sonic-test results for the Sears No. 1 well is given in table 6 .

\section{ELECTRICAL RESISTIVITY}

The electrical-resistivity measurements were made on the same samples used in the sonic velocity test. The samples were saturated in an aqueous solution containing $500 \mathrm{mg} / \mathrm{L} T D S .{ }^{5}$ The resistivity of this solution was measured and determined to be $11 \Omega \mathrm{m}$. The saturated samples were then covered with a jacket to isolate ends of the sample and confined at a pressure equivalent to $4.73 \times 10^{-4} \mathrm{~g} / \mathrm{cm}^{2}$ per centimeter of burial depth. A $30-\mathrm{Hz}$ source voltage was applied at the ends of the cylindrical sample. The resistance of the sample to this voltage was then determined. From this resistance, the resistivity of the sample was calculated and expressed in ohm-meters,

A summary of the resistivity values for each of the Sears No. 1 samples is contained in table 6 . The resistivity values are accurate to \pm 5 percent.

\section{MECHANICAL STRENGTH}

Unconfined compression tests were performed on all Sears No. 1 well samples to determine compressive strength. The samples were cylinders $3.81 \pm 0.05 \mathrm{~cm}$ in length and $1.91 \pm 0.013 \mathrm{~cm}$ in diameter. Sample ends were ground to within $0.00002-\mathrm{mm}$ flatness. Samples were tested with the "as-received" moisture content.

All loadings were applied quasi-statistically by using a constant displacement rate of $3.65 \pm 10^{-3} \mathrm{~cm}$. No strain measurements were taken. The transducer used to measure axial load is accurate to 2 percent.

The relation of axial stress to time graph for the various loadings was recorded. All samples, except the sample from $960 \mathrm{~m}$, demonstrated a similar response, and all samples experienced a brittle failure. There was no apparent increase in strength with increasing depth. A summary of the mechanical behavior is given in table 6 .

\section{EVALUATION OF POROSITY AND PERMEABILITY MEASUREMENTS}

\section{POROSITY}

Continuous porosity values for the Sears No. 1 well are available from the neutron-porosity and gamma-gamma density $\operatorname{logs}$ of plate 1 . In addition, porosity values

\footnotetext{
5 Based on water-quality analysis.
}

calculated for different matrix sonic velocities of $4.7 \mathrm{~km} / \mathrm{s}$, $5.3 \mathrm{~km} / \mathrm{s}$, and $6.0 \mathrm{~km} / \mathrm{s}$ are presented in table 2 .

The porosity determined from the geophysical logs differs from laboratory-determined porosity values of cores from equivalent depths. There are some differences among density-log, neutron-log, and sonic-log porosity values in table 2. The Sears No. 1 borehole wall is irregular and washed out, and the resulting effects of variable hole diameter may cause the discrepancies among porosity values determined by different techniques. The neutron-log response is particularly influenced by the shaly matrix of the Triassic rocks.

In table 3, average effective porosities determined from the porosity logs represent depth intervals where the borehole is reasonably smooth and is not washed out. Explanations for the apparent inconsistencies among the porosities determined from logs are given in the "Remarks" column of table 2 . The gamma-gamma density and neutron-porosity values for sandstone intervals generally agree within 15 percent. If the lithology of an interval is shale, the neutron-porosity value for that interval is high. The sonic-porosity value believed to be more accurate is calculated by using the lowest matrix velocity and is about equal to the gamma-gamma density value.

Laboratory-porosity values are lower, and the lack of consistency between laboratory-measured values and geophysical-log values is not understood. Factors that could cause such differences include

1. The laboratory test core sample was not representative of the volume of rock being sampled by the logging tool.

2. Crystal-structure changes had occurred in the rock core between the time the rock was cored and the time it was tested in the laboratory.

Laboratory-determined gas porosities for Sears No. 1 well and Deep River coal field samples below $152 \mathrm{~m}$ range from 0.83 percent to 12 percent, as shown in tables 6 and 7 . The average is about 3.5 percent.

\section{PERMEABILITY}

Laboratory air-permeability tests (tables 6 and 7) of core samples from the Sears No. 1 well and of drill hole samples from the Deep River coal field illustrate the low permeabilities characteristic of the Triassic rocks below the zone of weathering. Most values are in the square micrometer $\times 10^{-5}$ range. Attempts to determine liquid permeability with water having TDS similar to that of water pumped during packer tests of the Sears No. 1 well resulted in rupture of some samples having low permeability. The apparent sensitivity to the water composition 
indicates swelling of clays (or other mineralogic changes) caused by the use of water of probable different chemistry than that of formation water. Montmorillonite, which is highly expandable, is the most abundant clay in samples from the Sears No. 1 well. Also the water used in laboratory tests may not be truly representative of the formation water and could have the correct salinity but the wrong ionic composition.

\section{DETERMINATION OF GROUND-WATER QUALITY AND MOVEMENT}

\section{WATER QUALITY}

\section{CHEMICAL ANALYSIS OF WATER SAMPLES}

Water samples obtained from most shallow ground water (less than $90 \mathrm{~m}$ deep) are predominantly a calciumbicarbonate type. Dissolved-solids contents are generally less than $250 \mathrm{mg} / \mathrm{L}$. However, shallow ground water having a high dissolved-solids content (greater than 1,600 $\mathrm{mg} / \mathrm{L}$ ) is present in the area west and northwest of Cary, N.C., and north of Carpenter, N.C. From Cary, near the eastern border fault and basinward, sodium- and calciumsulfate types change progressively to calcium-chloride and sodium-chloride types. North of Carpenter, near the common corners of Durham, Chatham, and Wake Counties, some waters have a high (greater than $800 \mathrm{mg} / \mathrm{L}$ ) dissolved-solids content.

The wells that have a high dissolved-solids content are on the northwestern side of major faults and penetrate red mudstone or conglomerate having a red mudstone maxtrix. Thus, all the wells may be in a similar hydrogeologic situation at the discharge end of the basin's subsurface flow system. Water having high (greater than $1,600 \mathrm{mg} / \mathrm{L}$ ) dissolved solids present in shallow wells in the conglomerate and fanglomerate near Cary occurs near the deeper downfaulted parts of the basin.

Water from a depth of $115 \mathrm{~m}$ in the Sears No. 1 well (table 8) appears to be a sodium-chloride type similar to water from shallow depths in sample sites 4 and 38 (fig. 11). The water from the Sears No. 1 well 247 -m-depth to 264-m-depth interval is similar to water from sample sites 4 and 38 in that there is only a slight increase in the amount of calcium over sodium-ion concentration. The Sears No. 1 well water sample from the 1,009 -m-depth to 1,143-m-depth interval; although higher in dissolvedsolids content and calcium content than the water from either the 115-m-depth, 247-m-depth to 264-m-depth interval, or the drilling water, is known to be a blend of the drilling (mud filtrate) water and the formation water. A single inflatable packer was used to isolate a zone between the 1,009-m-depth and the bottom of the well at 1,143 m.
The small amount of water that did move into the test packer assembly from the 1,009-m-depth to 1,143-m-depth interval is probably a mixture of drilling-mud water and formation water (Bain and Brown, 1981).

The similarity of the chemical composition (chiefly sodium-calcium chloride types) of water from the buried Dunbarton, S.C., Triassic basin to that of the water of the Durham basin is striking. In contrast, ground water from the Culpeper, Va., basin to the northeast is a calcium-sulfate water, presumably caused by the widespread presence of gypsum. Water from sample 32 (table 9) near Cary (fig. 11) contains an ionic composition characteristic of water from the gypsum-bearing Permian Castile Formation near Jumping Springs, N. Mex., and the Triassic redbeds of the Newark basin, New Jersey. This similarity implies that gypsum may be present to influence the geochemistry of water near Cary.

\section{GEOPHYSICAL ANALYSIS}

\section{General Quality}

The borehole-geophysical logs were used to check the accuracy of properties measured from samples taken from the $247-\mathrm{m}$ to $264-\mathrm{m}$ and $1,009-\mathrm{m}$ to $1,143-\mathrm{m}$ zones and to give additional information on the water chemistry in the remainder of the hole.

\section{SALINITY}

The formation resistivity factor, also called the formation factor $(F)$, is defined as the electrical resistance of a rock that is saturated with a conducting electrolyte divided by the resistivity of the electrolyte; this factor is useful in analyzing the conductivity of fluids in rocks.

The salinity of formation waters is commonly estimated from the geophysical logs by using one or both of the following relationships (Alger, 1966; Schlumberger, Ltd., 1974 , p. 34$)$ :

$$
\text { 1. } S P=-\mathrm{K} \log \frac{R_{m f}}{R_{w}}
$$

where:

$S P=$ the spontaneous potential, in millivolts;

$\mathrm{K}=$ a constant related to absolute temperature;

$R_{m f}=$ the resistivity of the drilling mud filtrate, in ohmmeters at a specified temperature; and

$R_{w}=$ the resistivity of the formation water, in ohmmeters at a specified temperature. 
TABLE 8. - Chemical analysis of ground water [Latitude $35^{\circ} 41^{\prime} 33^{\prime \prime}$, longitude $78^{\circ} 56^{\prime \prime} 35^{\prime \prime}$. Dissolved con-

\begin{tabular}{|c|c|c|c|c|c|c|c|c|c|c|c|c|}
\hline $\begin{array}{c}\text { Depth of } \\
\text { sample } \\
\text { (m) }\end{array}$ & Date & $\begin{array}{c}\text { Sequence } \\
\text { No. }\end{array}$ & $\begin{array}{c}\text { Alkalinity } \\
\left(\text { total } \mathrm{CaCO}_{3}\right)\end{array}$ & $\begin{array}{c}\text { Bicarbonate } \\
\left(\mathrm{HCO}_{3}\right)\end{array}$ & $\underset{(C d)}{\text { Cadmium }}$ & $\begin{array}{l}\text { Calcium } \\
\text { (Ca) }\end{array}$ & $\begin{array}{l}\text { Carbonate } \\
\qquad\left(\mathrm{CO}_{3}\right)\end{array}$ & $\begin{array}{c}\text { Chloride } \\
\text { (Cl) }\end{array}$ & $\begin{array}{c}\text { Cobalt }{ }^{1} \\
\text { (Co) }\end{array}$ & $\begin{array}{l}\text { Copper } \\
\text { (Cu) }\end{array}$ & $\begin{array}{l}\text { Fluoride } \\
\text { (Fl) }\end{array}$ & $\begin{array}{c}\text { Noncarbonate } \\
\text { hardness }\end{array}$ \\
\hline 115 & $12 / 21 / 75$ & 11 & -- & -- & -- & -. & 17 & -- & - & -- & -- & -- \\
\hline Mudline & $04 / 04 / 76$ & 12 & - & - & - & $\ldots$ & 15 & -- & - & - & -- & -- \\
\hline 259 & $04 / 16 / 76$ & 1 & $\overline{85}$ & $\overline{104}$ & $\overline{0}$ & $\overrightarrow{18}$ & 0 & 93 & 0 & 1 & 0.5 & 0 \\
\hline 259 & $04 / 16 / 76$ & 4 & 0 & 0 & 3 & 62 & 0 & 83 & 32 & 300 & .8 & 170 \\
\hline 1,018 & $04 / 17 / 76$ & 8 & 0 & 0 & 4 & 30 & 0 & 41 & 14 & 130 & .5 & 84 \\
\hline 1,018 & $04 / 17 / 76$ & 9 & 0 & 0 & 1 & 96 & 0 & 200 & 31 & 420 & .9 & 250 \\
\hline 1,018 & $04 / 18 / 76$ & 10 & 0 & 0 & - & -- & 0 & 75 & - & -- & 1.4 & -- \\
\hline
\end{tabular}

Dissolved constituent in micrograms per liter.

TABLE 9. - Chemical analysis of ground [Modified from Bain and Brown, 1981.

\begin{tabular}{|c|c|c|c|c|c|c|c|c|c|c|c|c|c|}
\hline $\begin{array}{l}\text { Sam- } \\
\text { ple } \\
\text { site } \\
\text { No. }{ }^{1}\end{array}$ & $\begin{array}{c}\text { Well } \\
\text { depth } \\
(\mathrm{m})\end{array}$ & $\begin{array}{l}\text { Yield } \\
(\mathrm{L} / \mathrm{s})\end{array}$ & $\begin{array}{c}\text { Sample } \\
\text { date }\end{array}$ & Latitude $^{2}$ & Longitude $^{3}$ & $\begin{array}{c}\text { Sequence } \\
\text { No. }\end{array}$ & $\begin{array}{c}\text { Alkalinity } \\
\text { (total } \\
\mathrm{CaCO}_{3} \text { ) }\end{array}$ & $\begin{array}{c}\text { Bicarbonate } \\
\left(\mathrm{HCO}_{3}\right)\end{array}$ & $\begin{array}{l}\text { Calcium } \\
\text { (Ca) }\end{array}$ & $\begin{array}{c}\text { Carbonate } \\
\left(\mathrm{CO}_{3}\right)\end{array}$ & $\begin{array}{c}\text { Chloride } \\
\text { (Cl) }\end{array}$ & $\begin{array}{c}\text { Conductance } \\
(\mu \mathrm{mho})\end{array}$ & $\begin{array}{c}\text { Fluoride } \\
\text { (Fl) }\end{array}$ \\
\hline 1 & 61 & 0.01 & $05 / 09 / 73$ & 362832 & 784856 & 01 & 179 & 218 & 150 & 0 & 650 & 2,420 & 0.3 \\
\hline $2-$ & 30 & .06 & $05 / 09 / 73$ & 351708 & 794802 & 01 & 153 & 186 & 56 & 0 & 110 & 660 & .3 \\
\hline 3 & 67 & .32 & $05 / 09 / 73$ & 354721 & 794904 & 01 & 230 & 280 & 230 & 0 & 920 & 3,330 & .4 \\
\hline $4-$ & 53 & .32 & $05 / 09 / 73$ & 354704 & 794927 & 01 & 197 & 240 & 28 & 0 & 280 & 1,300 & .4 \\
\hline $5-$ & 30 & 1.1 & _- & 354739 & 795145 & 01 & 143 & 174 & 22 & 0 & 18 & 330 & .2 \\
\hline 6 & 53 & .13 & $05 / \overline{10} / 73$ & 354549 & 785408 & 01 & 115 & 140 & 11 & 0 & 4 & 240 & .2 \\
\hline 7 & 78 & .13 & $05 / 10 / 73$ & 350708 & 785208 & 01 & 128 & 156 & 24 & 0 & 10 & 270 & .2 \\
\hline 8 & 43 & .32 & $05 / 10 / 73$ & 354610 & 783357 & 01 & 164 & 200 & 31 & 0 & 10 & 330 & .1 \\
\hline 9 & 23 & .76 & $05 / 10 / 73$ & 355631 & 795514 & 01 & 167 & 204 & 42 & 0 & 56 & 500 & .2 \\
\hline 10 & 37 & 1.9 & $05 / 10 / 73$ & 354624 & 791606 & 01 & 11 & 13 & 3.5 & 0 & 5 & 67 & .1 \\
\hline 11 & - & -_ & $05 / 10 / 73$ & 364650 & 791718 & 01 & 67 & 82 & 12 & 0 & 24 & 220 & .3 \\
\hline 12 & 38 & $4 . \overline{7}$ & $05 / 10 / 73$ & 351650 & 781729 & 01 & 125 & 152 & 35 & 0 & 42 & 370 & .2 \\
\hline 13 & 59 & .32 & $05 / 10 / 73$ & 350737 & 790825 & 01 & 190 & 232 & 52 & 0 & 80 & 650 & .3 \\
\hline 14 & 37 & .63 & $05 / 11 / 73$ & 350722 & 790948 & 01 & 146 & 178 & 40 & 0 & 48 & 435 & .3 \\
\hline $15 \ldots$ & 34 & - & $05 / 11 / 73$ & 360648 & 792025 & 01 & 179 & 218 & 35 & 0 & 22 & 420 & .3 \\
\hline 16 & 30 &.$\overline{44}$ & $05 / 11 / 73$ & 350831 & 792057 & 01 & 161 & 196 & 78 & 0 & 130 & 740 & .2 \\
\hline $17 \ldots$ & 41 & .32 & - & 351144 & 782349 & 01 & 331 & 404 & 140 & 0 & 250 & 1,410 & .3 \\
\hline $18 \ldots$ & -- & - & $05 / \overline{11} / 73$ & 350108 & 785403 & 01 & 105 & 168 & 42 & 0 & 10 & 300 & .3 \\
\hline 19 & 30 & .25 & $05 / 11 / 73$ & 351012 & 781357 & 01 & 312 & 380 & 80 & 0 & 100 & 850 & .2 \\
\hline 20 & 12 & - & $05 / 11 / 73$ & 350920 & 791412 & 01 & 20 & 24 & 40 & 0 & 100 & 570 & .1 \\
\hline 21 & 24 & .32 & $05 / 11 / 73$ & 350922 & 790425 & 01 & 218 & 266 & 60 & 0 & 82 & 710 & 3 \\
\hline 22 & 145 & .19 & $05 / 12 / 73$ & 361822 & 784822 & 01 & 92 & 112 & 74 & 0 & 210 & 2,400 & .4 \\
\hline 23 & 32 & .32 & $05 / 14 / 73$ & 791408 & 791408 & 01 & 125 & 125 & 19 & 0 & 6 & 253 & 3 \\
\hline 24 & 53 & .38 & $05 / 14 / 73$ & 354705 & 791400 & 01 & 200 & 244 & 35 & 0 & 28 & 470 & .2 \\
\hline 25 & 30 & 1.4 & $05 / 14 / 73$ & 350651 & 791415 & 01 & 30 & 36 & 3.7 & 0 & 4 & 80 & .1 \\
\hline 26 & 34 & .16 & $05 / 14 / 73$ & 352735 & 781400 & 01 & 154 & 188 & 21 & 0 & 16 & 339 & .2 \\
\hline 27 & 76 & .13 & $05 / 14 / 73$ & 353556 & 785109 & 01 & 154 & 188 & 11 & 0 & 14 & 335 & .6 \\
\hline 28 & 46 & .32 & $05 / 14 / 73$ & 360244 & 791312 & 01 & $\begin{array}{r}62 \\
62\end{array}$ & 76 & 8.8 & 0 & 5 & 140 & .3 \\
\hline $29-$ & 99 & .09 & $05 / 14 / 73$ & 350305 & 791329 & 01 & 108 & 132 & 18 & 0 & 11 & 250 & .6 \\
\hline 30 & 24 & 1.1 & $05 / 15 / 73$ & 352517 & 792340 & 01 & 116 & 142 & 18 & 0 & 4 & 230 & .3 \\
\hline $31 \ldots$ & 33 & .63 & $05 / 15 / 73$ & 350442 & 791348 & 01 & 116 & 142 & 21 & 0 & 3.5 & 230 & .3 \\
\hline 32 & 122 & .95 & $05 / 15 / 73$ & 351002 & 790940 & 01 & 87 & 106 & 100 & 0 & 4 & 620 & 3 \\
\hline $33--$ & 183 & .63 & 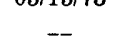 & 355615 & 792254 & 01 & 154 & 188 & 5.2 & 0 & 36 & 415 & .7 \\
\hline 34 & 107 & .95 & $05 / \overline{18} / 73$ & 355615 & 792254 & 01 & 80 & 98 & 11 & 0 & 7 & 190 & .2 \\
\hline 35 & 91 & .76 & $05 / 21 / 73$ & 355440 & 792050 & 01 & 75 & 92 & 11 & 0 & 3 & 160 & .2 \\
\hline 36 & 232 & .38 & $05 / 23 / 73$ & 351556 & 795100 & 01 & 105 & 128 & 15 & 0 & 18 & 285 & .2 \\
\hline $37--$ & 152 & .19 & $05 / 23 / 73$ & 355407 & 791604 & 01 & 190 & 232 & 36 & 0 & 300 & 1,350 & .5 \\
\hline 38 & 88 & .09 & $06 / 04 / 73$ & 360548 & 792025 & 01 & 149 & 182 & 16 & 0 & 3.4 & $\begin{array}{r}1,000 \\
300\end{array}$ & .3 \\
\hline \multicolumn{7}{|c|}{ Mean } & 140.5 & 171.6 & 43 & & 96 & 635 & 0.287 \\
\hline \multicolumn{7}{|c|}{ Standard deviation } & 68 & 82.9 & 46.4 & & 185 & 705 & .136 \\
\hline \multicolumn{7}{|c|}{ Median } & 144.5 & 176 & 29.5 & & 20 & 354 & .300 \\
\hline \multicolumn{7}{|c|}{ Maximum } & 311 & 404 & 23.0 & & 920 & 3,300 & .700 \\
\hline \multicolumn{7}{|c|}{ Minimum _ } & 11 & 13 & 3.5 & & 3 & 67 & .100 \\
\hline
\end{tabular}

${ }^{1}$ On figure 11.

"For example, $36^{\circ} 28^{\prime} 32^{\prime \prime}$

"Dissolved constituent, in micrograms per liter. 
from the Sears No. 1 well, North Carolina

stituents in $\mathrm{mg} / \mathrm{L}$ unless indicated otherwise. --means no data]

\begin{tabular}{|c|c|c|c|c|c|c|c|c|c|c|c|c|}
\hline $\begin{array}{c}\text { Total } \\
\text { hardness }\end{array}$ & $\begin{array}{l}\text { Iron }^{1} \\
(\mathrm{Fe})\end{array}$ & $\begin{array}{l}\text { Lead }^{1} \\
(\mathrm{~Pb})\end{array}$ & $\begin{array}{l}\text { Magnesium } \\
\text { (Mg) }\end{array}$ & $\underset{(\mathrm{Mn})}{\text { Manganese }^{1}}$ & $\begin{array}{c}\mathrm{pH} \\
\text { (field } \\
\text { measurement) }\end{array}$ & $\begin{array}{l}\text { Potassium } \\
\text { (K) }\end{array}$ & $\begin{array}{l}\text { Residue } \\
\text { (calculated } \\
\text { sum) }\end{array}$ & $\begin{array}{l}\text { Sodium } \\
\text { absorption } \\
\text { ratio }\end{array}$ & $\begin{array}{l}\text { Silica } \\
\left(\mathrm{SiO}_{2}\right)\end{array}$ & $\begin{array}{l}\text { Sodium } \\
\text { (Na) }\end{array}$ & $\begin{array}{l}\text { Sulfate } \\
\left(\mathrm{SO}_{4}\right)\end{array}$ & $\begin{array}{c}\operatorname{Zinc}^{1} \\
(\mathrm{Zn})\end{array}$ \\
\hline 52 & -- & -- & 2.3 & -- & 8.9 & 3.2 & -- & 7.9 & _- & 130 & _- & --. \\
\hline 39 & -- & -- & .3 & - & .8 & -- & - & & -- & & -- & -- \\
\hline 47 & -10 & 0 & .4 & $\overline{380}$ & 8.5 & $\overline{4.8}$ & $\overline{283}$ & $\overline{5.6}$ & $\overline{3.9}$ & 88 & 23 & 30 \\
\hline 170 & 26,000 & 2,000 & 2.6 & 3,400 & 8.9 & 10 & 342 & 3.2 & 28 & 96 & 16 & 12,000 \\
\hline 84 & 12,000 & 2,000 & 2.1 & 1,600 & 9 & 5.7 & 179 & 1.9 & 19 & 40 & 14 & 11,000 \\
\hline 250 & 31,000 & 4,200 & 3.4 & 4,300 & 9 & 11 & 535 & 3.6 & 34 & 130 & 9.7 & 10,000 \\
\hline -- & -- & - & -- & - & 8.9 & -- & -- & -- & 82 & -- & 1.4 & -- \\
\hline
\end{tabular}

water from the Durham basin, North Carolina

Dissolved constituents in $\mathrm{mg} / \mathrm{L}$, unless indicated otherwise. -- means no datal

\begin{tabular}{|c|c|c|c|c|c|c|c|c|c|c|c|c|c|}
\hline $\begin{array}{l}\text { Noncarbonate } \\
\text { hardness }\end{array}$ & $\begin{array}{c}\text { Total } \\
\text { hardness }\end{array}$ & $\begin{array}{c}\text { Iron }^{4} \\
(\mathrm{Fe})\end{array}$ & $\begin{array}{l}\text { Magnesium } \\
(\mathrm{Mg})\end{array}$ & $\begin{array}{c}\text { Manganese } \\
\text { (Mn) }\end{array}$ & $\begin{array}{c}\text { Nitrate } \\
\left(\mathrm{NO}_{3}\right)\end{array}$ & $\begin{array}{c}\mathrm{pH} \\
\text { (field } \\
\text { measurement) }\end{array}$ & $\begin{array}{c}\text { Potassium } \\
(\mathrm{K})\end{array}$ & $\begin{array}{c}\text { Residue } \\
\text { (calculated } \\
\text { sum) }\end{array}$ & $\begin{array}{c}\text { Residue } \\
\text { (dissolved) }\end{array}$ & $\begin{array}{l}\text { Silica } \\
\left(\mathrm{SiO}_{2}\right)\end{array}$ & $\begin{array}{l}\text { Sodium } \\
\text { (Na) }\end{array}$ & $\begin{array}{l}\text { Strontium } \\
\text { (Sr) }\end{array}$ & $\begin{array}{c}\text { Sulfate } \\
\left(\mathrm{SO}_{4}\right)\end{array}$ \\
\hline 470 & 650 & 40 & 66 & 70 & & 6.8 & 3.4 & 1,300 & 1,580 & 48 & 220 & 2,200 & 16 \\
\hline 120 & 270 & 10 & 31 & 0 & 1.8 & 7.5 & 2.1 & 340 & 384 & 31 & 19 & 400 & .8 \\
\hline 870 & 1,100 & 30 & 120 & 10 & .4 & 6.8 & 4.2 & 2,020 & 2,410 & 32 & 220 & 2,800 & .8 \\
\hline 0 & 87 & -- & 4 & -- & 0 & 7.8 & 3.5 & 680 & 715 & 12 & 240 & 400 & 8.8 \\
\hline 0 & 100 & 0 & 11 & 0 & .9 & 6.8 & 1.8 & 200 & 205 & 30 & 30 & 340 & .8 \\
\hline 0 & 45 & -- & 4.3 & -- & 0 & 7.6 & 1.6 & 150 & 160 & 27 & 35 & 23 & .8 \\
\hline 0 & 92 & - & 7.7 & - & 2.2 & 7.0 & 2.2 & 180 & 182 & 32 & 25 & 460 & .8 \\
\hline 0 & 110 & -- & 8.2 & - & 0 & 8.0 & 1.7 & 210 & 215 & 24 & 32 & 640 & .8 \\
\hline 0 & 150 & -- & 12 & -- & .4 & 6.8 & 1.8 & 290 & 297 & 31 & 44 & 220 & .8 \\
\hline 2 & 13 & 20 & .9 & 10 & 9.3 & 5.9 & 1.7 & 69 & 70 & 34 & 6.9 & 80 & .8 \\
\hline 0 & 50 & - & 4.8 & $\ldots$ & .4 & 6.5 & .8 & 160 & 174 & 48 & 27 & 220 & 5.6 \\
\hline 0 & 120 & -- & 7.4 & - & .4 & 6.4 & .9 & 240 & 241 & 44 & 29 & 740 & .8 \\
\hline 0 & 150 & -- & 5 & -- & .4 & 7.5 & .7 & 380 & 388 & 34 & 80 & 1,400 & 10 \\
\hline 0 & 120 & 10 & 5.4 & $\overline{100}$ & $0^{-7}$ & 7.1 & .7 & 270 & 262 & 34 & 45 & 1,100 & 4 \\
\hline 0 & 130 & 170 & 11 & 370 & .9 & 7.5 & .6 & 250 & 268 & 30 & 39 & 600 & 8.4 \\
\hline 89 & 250 & 130 & 13 & 810 & 0 & 7.4 & .7 & 410 & 490 & 32 & 47 & 1,800 & 8.8 \\
\hline 240 & 570 & 30 & 52 & 40 & 6.2 & 7.4 & 2.5 & 810 & 864 & 21 & 68 & 2,200 & 68 \\
\hline 15 & 120 & 40 & 3.7 & 280 & 0 & 7.7 & .9 & 200 & 208 & 37 & 19 & 860 & 1.6 \\
\hline 0 & 220 & 60 & 4 & 90 & 3.1 & 7.5 & .7 & 500 & 500 & 22 & 100 & 2,400 & 6.4 \\
\hline 150 & 170 & 180 & 17 & 10 & 44 & 6.2 & 1.2 & 380 & 380 & 52 & 34 & 360 & 34 \\
\hline 32 & 250 & -- & 25 & -- & 1.3 & 6.8 & 1.4 & 410 & 455 & 44 & 48 & 400 & 14 \\
\hline 130 & 220 & 40 & 7.5 & $\overline{290}$ & .3 & 8 & 3.4 & 417 & 1,500 & 12 & 430 & - & 700 \\
\hline 0 & 67 & 20 & 4.7 & 30 & $0^{.0}$ & 7 & 1.4 & 170 & 167 & 34 & 31 & $\overrightarrow{360}$ & .2 \\
\hline 0 & 120 & 50 & 8.8 & 30 & .3 & 7.8 & 2.2 & 280 & 287 & 27 & 56 & 640 & 4.4 \\
\hline 0 & 15 & 700 & 1.3 & 30 & 1.3 & 6.3 & .8 & 79 & 63 & 39 & 11 & 70 & .4 \\
\hline 0 & 75 & 30 & 5.4 & 10 & .4 & 7.5 & 1.4 & 210 & 197 & 27 & 45 & 370 & .4 \\
\hline 0 & 35 & 0 & 1.8 & 0 & .3 & 8.5 & 1.2 & 210 & 204 & 20 & 65 & 210 & .4 \\
\hline 0 & 37 & 2,200 & 3.7 & 80 & 0 & 6.3 & 1.4 & 120 & 113 & 44 & 15 & 120 & \\
\hline 0 & 75 & 40 & 7.2 & 40 & 0 & 7.3 & 2.9 & 160 & 157 & 33 & 24 & 320 & 2 \\
\hline 0 & 78 & 820 & 8 & 80 & 0 & 7.2 & 2.2 & 160 & 150 & 37 & 20 & 300 & .4 \\
\hline 0 & 77 & 70 & 5.9 & 30 & 0 & 7.7 & 3.4 & 150 & 149 & 29 & 20 & 360 & .4 \\
\hline 210 & 300 & 3,200 & 13 & 1,900 & 0 & 7 & .6 & 430 & 461 & 29 & 10 & 120 & 220 \\
\hline 0 & 16 & 10 & .7 & 20 & 0 & 8.7 & .8 & 250 & 254 & 19 & 90 & 50 & 5.2 \\
\hline 0 & 37 & 30 & .2 & 10 & 1.8 & 7.7 & 1.0 & 130 & 130 & 33 & 26 & 140 & 1.2 \\
\hline 0 & 40 & 80 & .2 & 190 & .3 & 7.6 & 1.4 & 120 & 119 & 34 & 19 & 100 & 2.8 \\
\hline 0 & 65 & 370 & .2 & 20 & 8.4 & 7.5 & 1.8 & 190 & 177 & 37 & 34 & 130 & 2 \\
\hline 0 & 150 & 30 & .5 & 10 & .9 & 8.7 & 2.6 & 740 & 724 & 38 & 220 & 520 & 10 \\
\hline 0 & 52 & 10 & .3 & 10 & 0 & -- & 1.8 & 180 & 196 & 18 & 51 & 280 & .8 \\
\hline -- & 164 & 26 & 12.7 & 158 & 2.38 & 7.3 & 1.72 & 354 & 408 & 31.32 & & 30 & 641 \\
\hline-- & 206 & 742 & 3.6 & 374 & 7.47 & .658 & .952 & 366 & 474 & 9.33 & & 117 & 727 \\
\hline & 205 & 40 & 5.6 & 30 & .4 & 7.45 & 1.5 & 225 & 228 & 32 & & 2 & 360 \\
\hline 870 & 1,100 & 3,200 & 120 & 1,900 & 44 & 8.7 & 4.2 & 2,020 & 2,410 & 52 & & 700 & 2,800 \\
\hline 0 & 13 & 10 & .2 & 0 & 0 & 5.9 & .6 & 69 & 63 & 12 & & 0 & 23 \\
\hline
\end{tabular}


The relation of $F$ to porosity ( $\phi$ ), formation water resistivity $\left(R_{w}\right)$, and true resistivity of rocks saturated with the formation water (Rt) (Archie, 1942) is

$$
\text { 2. } F=\frac{R t}{R_{w}}=\frac{1}{\phi^{m}},
$$

where $m$, the cementation factor $=1.3$ to 2.6 , and $\phi=$ porosity, in percent.

The Humble formula, $\mathbf{F}=0.62^{-2.15}$, is commonly used for granular rocks. Water resistivity at five depths in the Sears No. 1 well derived from the relation $R_{w}=\frac{R t}{F}$ is given in table 10 (col. 4 ). $F$ values are determined from laboratory analyses, and $R t$ values are taken from the deep induction curve (ILD) of plate 1 .

Table 10 shows that the calculated values of $R_{w}$ ranged from about 1.0 to $14 \Omega \mathrm{m}$. These data indicate that formation waters at the Sears No. 1 well site could have a dissolved-solids equivalent that ranges from about 350 to $5,500 \mathrm{mg} / \mathrm{L}$ as sodium chloride.

The analyses of water samples collected from the $247-\mathrm{m}$ depth to 264-m-depth interval indicate a dissolved-solids concentration of approximately $560 \mathrm{mg} / \mathrm{L}$ when corrected to equivalent sodium chloride. Alger (1966), Schlumberger, Ltd. (1972), and Brown (1971) indicate that, at $25^{\circ} \mathrm{C}$, water containing $560 \mathrm{mg} / \mathrm{L}$ sodium chloride should have a resistivity of about $10 \Omega \mathrm{m}$. No laboratory $F$ data are available for the 247-m-depth to 264-m-depth interval; however, water resistivities calculated from $F$ values above and below the sampled zone are approximately $10 \Omega \mathrm{m}$. Similarly, $R_{w}$ values from laboratorymeasured porosity and $R t$ values from the ILD indicate that interstitial water below $960 \mathrm{~m}$ is not highly saline. This formation water, which has a resistivity of 1 to $2 \Omega \mathrm{m}$ at $25^{\circ} \mathrm{C}$, is equivalent to a sodium-chloride concentration of 2,200 to $4,500 \mathrm{mg} / \mathrm{L}$. The analysis of water sampled from the 1,018-m-depth to 1,143 -m-depth interval indicates a much less saline water.

Water resistivities also were calculated (table 10, col. 7 ) by using $F$ values derived from $\log$ porosities $(\phi)$ :

$$
F=\frac{R t}{R_{w}}=\frac{1}{\phi^{m}}
$$

where $F, R t, R_{w}$, and $\phi$ are the notations described previously and $m$ is the "appropriate" cementation factor (Schlumberger, Ltd., 1972). Log-derived $F$ values determined by this equation are frequently one to two orders of magnitude lower than those calculated by using laboratory porosities. Values determined from log data give extreme $F$ values, which can be directly related to the range of porosity values.

Figures 12 and 13 are graphs showing the relation of porosity from the density and sonic logs to resistivity from the induction log (ILD). There appears to be some correlation between the measured variables on these figures. Apparent $R_{w}$ values were calculated by Schlumberger, Ltd. (written commun., 1977), from the same ILD data and by using the same equation:

$$
F=\frac{R t}{R_{w}}=\frac{1}{\phi^{m}} .
$$

The values ranging from $0.41 \Omega \mathrm{m}$ at $152 \mathrm{~m}$ to $0.35 \Omega \mathrm{m}$ at the bottom of the well indicate sodium chloride concentrations of about $11,000 \mathrm{mg} / \mathrm{L}$.

The explanation for the disparity is apparently related to the assumption that $F=\frac{1}{\phi^{2}}$ at low dissolved-solids concentrations and low porosities. Alger (1966) states, "*** the customary relationships between $F$ and porosity used in oil field interpretations usually do not apply to freshwater sands.***F varies in freshwater sands not only with porosity, but also with $R_{w}$ and grain size."

Data from the computation of formation water resistiv-

ity based on the relation $S P=-\mathrm{K} \log \frac{R_{m f}}{R_{w}}$ are presented in table 11 (Schlumberger, Ltd., 1974, p. 34). The $S P$ values given in table 11 are calculated by using a log deflection of $5 \mathrm{mV}$ per division. Formation factors calculated from the $S P$-log-derived $R_{w}$ and from $R t$ from the ILD curve are given in table 12 . Calculated $R_{w}$ for the 247-m-depth to 264-m-depth interval ranges from 5.3 to $12.4 \Omega \mathrm{m}$ at $25^{\circ} \mathrm{C}$ (table 11, col. 8). However, the $R_{w}$ values shown in table 11 increase with depth, contrary to most natural occurrences. The use of the $S P$ deflection to obtain reliable $R_{w}$ values opposite very low permeability formations may make the results less accurate in some cases.

\section{MOVEMENT}

A ground-water flow map was not completed for this study. Ground water having dissolved-solids content greater than $2,400 \mathrm{mg} / \mathrm{L}$-chiefly calcium-sodium chloride types-occurs along the basin's eastern edge from Morrisville to Cary and southwest to Holly Springs, N.C. (fig. 11). The location of these occurrences relative to the downfaulted blocks along the east side of the basin indicates that the probable source of the high dissolved-solids-content water is from movement of water upward along fracture zones that bound the 
TABLE 10.-Formation water resistivities calculated by using laboratory measurements and porosity-log data, Sears No. 1 well, North Carolina

[--, no data]

\begin{tabular}{|c|c|c|c|c|c|c|}
\hline $\begin{array}{c}\text { Depth } \\
\text { (m) }\end{array}$ & $\begin{array}{l}\text { Formation } \\
\text { factor, } F \\
\text { (measured in } \\
\text { laboratory) }\end{array}$ & $\begin{array}{c}\text { True } \\
\text { resistivity, } \\
R t, \text { from ILD } \\
(\Omega \mathrm{m})\end{array}$ & $\begin{array}{c}\text { Water } \\
\text { resistivity, } R_{w}{ }^{\prime} \\
\text { calculated by using } \\
F \text { derived from } \\
\text { laboratory analyses } \\
\text { and } R t \text { from ILD } \\
(\Omega \mathrm{m})\end{array}$ & $\begin{array}{c}\text { Porosity, } \\
\text { from porosity } \\
\text { log } \\
\text { (percent) }\end{array}$ & $\begin{array}{c}\text { Formation } \\
\text { factor, } \\
F=1 /(\text { porosity })^{2} \\
\text { (calculated from } \\
\text { log porosity) }\end{array}$ & $\begin{array}{c}\text { Water } \\
\text { resistivity, } \mathrm{R}_{\mathrm{w}},{ }^{1} \\
\text { calculated by } \\
\text { using } R t \text { and } F \\
\text { derived from logs } \\
(\Omega \mathrm{m})\end{array}$ \\
\hline 154 & 2.74 & 40 & 14.6 & 5 & 400 & 0.10 \\
\hline 157 & 25.0 & 80 & 3.2 & 8.9 & 127 & .63 \\
\hline 330 & 3.64 & 50 & 13.7 & 4.7 & 452 & .11 \\
\hline 744 & 6.5 & 75 & 11.5 & .9 & 12,346 & .006 \\
\hline 960 & 96 & 80 & $1.04-2.08$ & 2.8 & 1,275 & $0.078-0.157$ \\
\hline 1,138 & 67 & 100 & 1.00 & 2.5 & 1,600 & .06 \\
\hline 1,142 & 18 & $>100$ & -- & .9 & 12,346 & - \\
\hline
\end{tabular}

${ }^{\prime} R=R t / F$.

${ }^{2}$ Small range in porosity and salinity of formation water increases error for calculation of $R_{\psi}$.

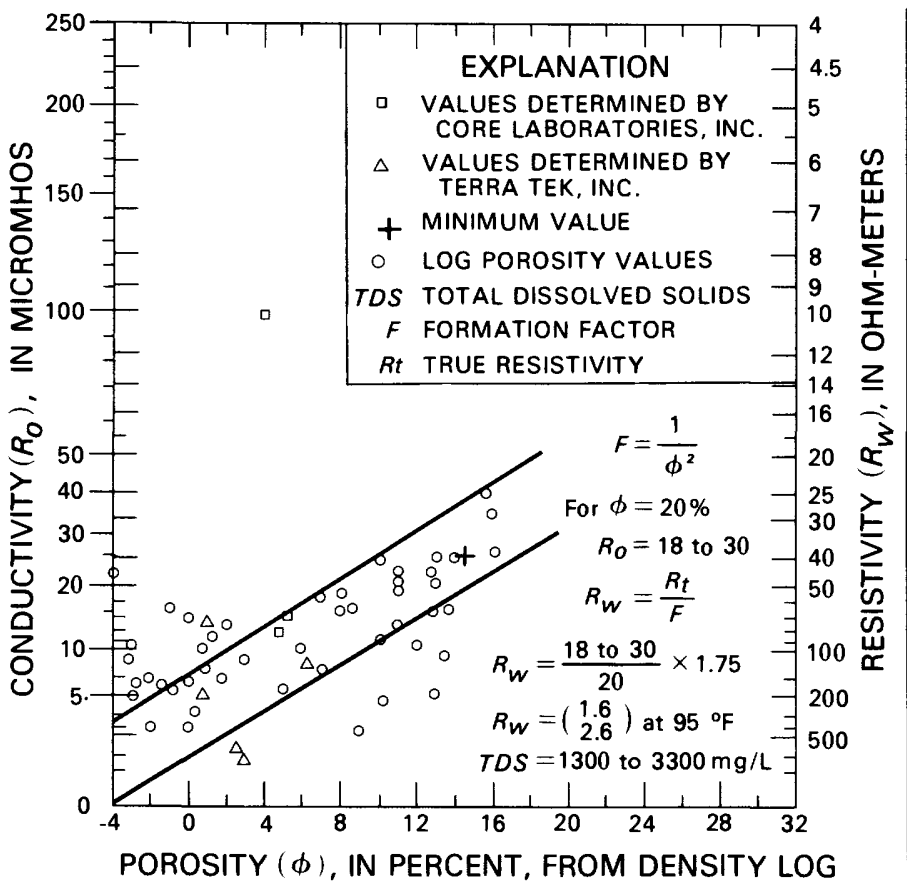

FIGl'RE 12.-Relation of porosity determined from density $\log$ to resistivity and conductivity of rocks in the Sears No. 1 well, North Carolina.

blocks. The temperature log, however, indicates apparent upward movement of water to the $550-\mathrm{m}$ zone and downward movement to the 500-m zone. The resistivity and $S P$ logs from the Sears No. 1 well indieate that the formation water is relatively fresh $(<4,500 \mathrm{mg} / \mathrm{L}$ dissolved-solids contents) to the bottom of the hole. The lower gradient of the Sears No. 1 well temperature log suggests deep circulation at this site. In contrast, the temperature gradient of the Groce No. 1 well indicates poor ground-water circulation in the Sanford area (Bain and Brown, 1981).

The low values of permeabilities of the core samples and the low temperature gradient from the temperature log indicate that circulation in the unweathered rock in the subsurface may be through fractures.

\section{CONCLUSIONS}

Tests indicate that low porosities and low permeabilities for the rocks in the Durham Triassic basin are the result of the depositional environment, which limited sorting of sediment, caused extensive lithification and cementation, and possibly caused the presence of montmorillinite.

The low temperature gradient $\left(1^{\circ} \mathrm{C} / 66 \mathrm{~m}\right)$ and the presence of relatively freshwater throughout the Sears No. 1 test well are an indication of deep circulation, probably through fractures.

The lithologic log and borehole-geophysical logs from the Groce No. 1 well and the Sears No. 1 well confirm the simultaneous deposition of different facies in separate parts of the basin, the cyclic nature of sediment deposition, and the general imperviousness of the rocks. The logs from the Sears No. 1 well indicate that slightly permeable sandstones and siltstones of the tan arkosic unit interfinger with dense, essentially impervious, red mudstones and argillites. The lateral extent of these sandstones and siltstones is limited by the nearest impermeable facies and the boundaries of the individual structural blocks.

Porosity determined from the density logs is slightly higher than that determined from the laboratory analysis of core samples. The mean density-log 
TABLE 11. - Formation water resistivities calculated by using spontaneous-potential-log data, Sears No. 1 well, North Carolina [-- means no data]

\begin{tabular}{|c|c|c|c|c|c|c|c|c|c|}
\hline \multirow{2}{*}{$\begin{array}{l}\text { Depth } \\
\text { to top } \\
\text { of zone } \\
\text { (m) }\end{array}$} & \multirow{2}{*}{$\begin{array}{c}\text { Spontaneous } \\
\text { potential, } \\
\text { SP } \\
(\mathrm{mV})\end{array}$} & \multicolumn{2}{|c|}{$\begin{array}{c}\text { Formation } \\
\text { temperature, } \\
S P \log \\
\end{array}$} & \multirow{2}{*}{$\begin{array}{l}\text { Resistivity of } \\
\text { mud filtrate, } R_{m f} \text {, } \\
\text { at formation } \\
\text { temperature } \\
(\Omega \mathrm{m})\end{array}$} & \multirow{2}{*}{$\begin{array}{c}\text { Resistivity } \\
\text { factor }^{2} \\
\text { (when } K=70 \text { ) } \\
(\Omega \mathrm{m})\end{array}$} & \multirow{2}{*}{$\begin{array}{l}\text { Equivalent } \\
\text { water } \\
\text { resistivity, } \\
R_{\text {we, }} \text { at } \\
\text { formation } \\
\text { temperature } \\
(\Omega \mathrm{m})\end{array}$} & \multirow{2}{*}{$\begin{array}{c}\text { Water } \\
\text { resistivity, } \\
R_{w}, \text { from } \\
R_{w \neq} \text { at } 25^{\circ} \mathrm{C}^{4} \\
\text { (NaCl-type } \\
\text { water) } \\
(\Omega \mathrm{m})\end{array}$} & \multirow{2}{*}{ 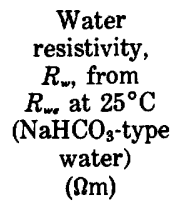 } & \multirow[t]{2}{*}{$\begin{array}{l}\text { Resistivity } \\
\text { from ILD } \\
(\Omega \mathrm{m})\end{array}$} \\
\hline & & ${ }^{\circ} \mathrm{F}$ & ${ }^{\circ} \mathrm{C}$ & & & & & & \\
\hline 154 & +10 & 71.5 & 22 & 21.6 & 0.72 & 30 & 28 & 49 & 45 \\
\hline 191 & -11 & 72 & 22 & 21.6 & 1.48 & 14.6 & 13.6 & 25 & 210 \\
\hline 220 & -17 & 73 & 23 & 21.4 & 1.70 & 12.6 & 12.2 & 21 & 700 \\
\hline 229 & -36 & 73 & 23 & 21.4 & 3.25 & 6.58 & 6.2 & 11 & 120 \\
\hline 248 & -39 & 74 & 23 & 21.3 & 3.70 & 5.73 & 5.3 & 9 & 45 \\
\hline 257 & -16 & 74 & 23 & 21.3 & 1.70 & 12.5 & 12.1 & 21 & -- \\
\hline 259 & -21 & 74 & 23 & 21.3 & 2.03 & 10.4 & 10 & 18 & --- \\
\hline 262 & -15 & 74 & 23 & 21.3 & 1.65 & 12.8 & 12.4 & 22 & --- \\
\hline 270 & -18 & 74.5 & 23 & 21.1 & 1.77 & 11.9 & 11.4 & 20 & 30 \\
\hline 278 & -18 & 75 & 24 & 21.1 & 1.77 & 11.9 & 11.4 & 20 & --- \\
\hline 282 & -15 & 75 & 24 & 21.1 & 1.65 & 12.8 & 12.4 & 22 & --- \\
\hline 289 & -23 & 75 & 24 & 21.1 & 2.30 & 9.17 & 9 & 16 & 70 \\
\hline 306 & -17 & 76 & 24 & 20.9 & 1.70 & 12.3 & 12 & 21 & 800 \\
\hline 338 & -17 & 76.5 & 24 & 20.9 & 1.80 & 11.6 & 11.6 & 20 & 190 \\
\hline 377 & -20 & 78 & 26 & 20.4 & 1.96 & 10.4 & 10.5 & 18 & 40 \\
\hline 398 & -34 & 78 & 26 & 20.4 & 3.20 & 6.38 & 6.27 & 11 & 80 \\
\hline 413 & -20 & 78.5 & 26 & 20.3 & 1.96 & 10.36 & 10.7 & 19 & -- \\
\hline 440 & -25 & 79 & 26 & 20.1 & 2.33 & 8.62 & 8.9 & 16 & 70 \\
\hline 477 & -15 & 80.5 & 27 & 19.8 & 1.65 & 13.2 & 14.5 & 25 & - \\
\hline 478 & -14 & 80.5 & 27 & 19.8 & 1.60 & 12.4 & 13 & 23 & --- \\
\hline 508 & -4 & 81 & 27 & 19.7 & 1.11 & 17.7 & 19 & 33 & 120 \\
\hline 526 & -16 & 82 & 28 & 19.5 & 1.70 & 11.5 & 12.3 & 22 & 100 \\
\hline 570 & -7 & 83 & 28 & 19.3 & 1.20 & 16.1 & 17 & 30 & 80 \\
\hline 582 & -20 & 83 & 28 & 19.3 & 1.96 & 9.85 & 11 & 19 & --- \\
\hline 609 & -4 & 84 & 29 & 19.1 & 1.11 & 17.2 & 19 & 33 & --- \\
\hline 633 & -15 & 84.5 & 29 & 19 & 1.65 & 11.5 & 13.6 & 24 & -- \\
\hline 999 & -5 & 93.5 & 34 & 17 & 1.17 & 14.5 & 17.5 & 31 & --- \\
\hline 1,019 & -26 & 94 & 34 & 16.9 & 2.35 & 7.19 & 8.7 & 15 & 150 \\
\hline 1,025 & -14 & 94 & 34 & 16.9 & 1.60 & 10.6 & 13 & 23 & -- \\
\hline 1,043 & -13 & 95 & 35 & 16.7 & 1.52 & 13.9 & 17 & 30 & --- \\
\hline 1,057 & -8 & 95 & 35 & 16.7 & 1.28 & 13 & 16 & 28 & --- \\
\hline 1,082 & -5 & 95.5 & 35 & 16.6 & 1.17 & 14.2 & 17.2 & 30 & -- \\
\hline 1,102 & -6 & 96.5 & 36 & 16.4 & 1.20 & 13.7 & 16.8 & 29 & -- \\
\hline 1,108 & -5 & 97 & 36 & 16.3 & 1.17 & 13.9 & 17.5 & 31 & 160 \\
\hline
\end{tabular}

'Recorded from log heading.

${ }^{2}$ Factor in $S P$ equation (see Schlumberger, Ltd., 1972, p. 79) $=R_{m} / R_{w .} . \mathrm{K}$, constant related to absolute temperature.

${ }^{3}$ Schlumberger, Ltd. (1972, p. 79).

${ }^{4}$ Value estimated from Schlumberger, Ltd. (1972, fig 13-3, p. 79).

porosity was approximately 6 percent, whereas the laboratory-tested core's porosity was approximately 5 percent. However, porosities derived from the neutron and sonic logs are substantially higher than either the mean density-log porosity or the laboratory-tested core porosity. Undoubtedly, part of this difference is due to inadequately compensating for hole irregularity when making logs, and part may be due to postdrilling mineralogical changes in the core prior to testing. However, the higher porosities determined for the Sears No. 1 well are consistent with those observed for the Groce No. 1 well.

Attempts to determine permeabilities with liquids in cores in the laboratory resulted in rupture of some samples. The ruptured core that contained interstitial clay was sensitive to the chemistry of the water-namely, the presence and type of dissolved solids. Later during clay analysis, montmorillonite was found to be the most abundant clay present in the Sears No. 1 well drill cuttings.
The expansion of montmorillonite probably affected the results of some of the in-hole and laboratory analyses.

Insufficient data were available to construct a potentiometric map and to establish the rate and direction of movement of ground water in the basin. The low temperature gradient of the Sears No. 1 well indicates deeper circulation of ground water at the Sears No. 1 wellsite, and the sonic log does not indicate that any of the shales are overpressured. The shape of the temperature anomalies on the Sears No. 1 log suggests that there is a little water movement vertically downward above a depth of $550 \mathrm{~m}$ and vertically upward below a depth of $550 \mathrm{~m}$. If deep circulation does occur at the Sears No. 1 well site, circulation must take place through an extensive fracture system. Acoustic-televiewer images of selected parts of the Sears No. 1 wellbore show many irregular openings that appear to be parallel to bedding and may be related to either fractures or crossbedding. 
POROSITY $(\phi)$, IN PERCENT, FOR SANDSTONE-MATRIX SONIC VELOCITY $=5.49$ KILOMETERS PER SECOND

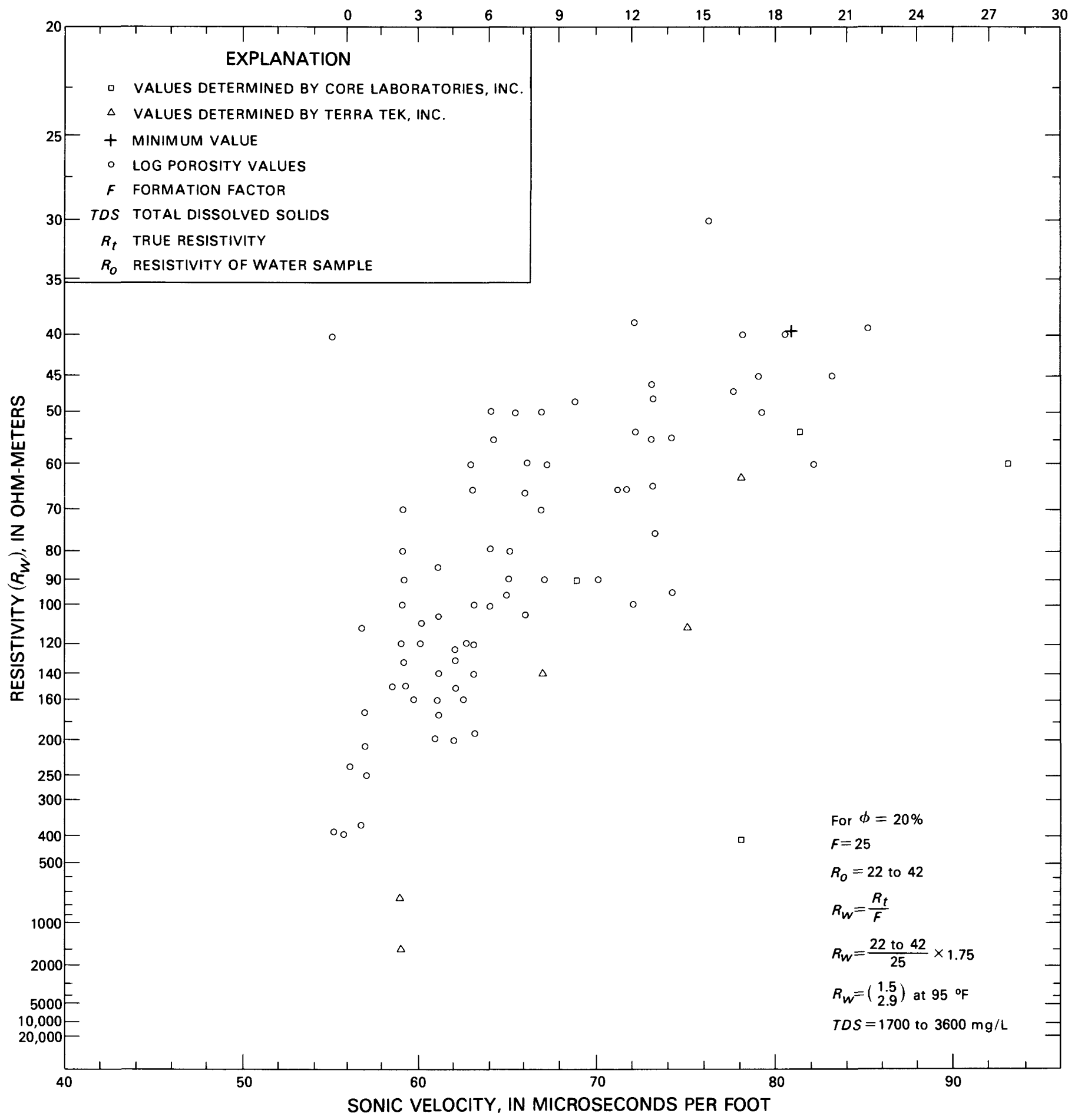

FIGURE 13.- Relation of porosity determined from sonic log to resistivity of rocks on the Sears No. 1 well, North Carolina. 
TABLE 12. -Formation factor calculated from spontaneous-potential-log-derived water resistivities and from induction-log-derived true resistivities, Sears No. 1 well, North Carolina

[-- means no data]

\begin{tabular}{|c|c|c|c|c|c|c|}
\hline & $\begin{array}{l}\text { epth to } \\
\text { op of zone } \\
\text { n) }\end{array}$ & $\begin{array}{c}\text { True resistivity }(R t) \\
\text { from ILD at formation } \\
\text { temperature } \\
(\Omega \mathrm{m})\end{array}$ & $\begin{array}{l}\text { Water resistivity } \\
\left(R_{w}\right) \text { from } S P \text { log } \\
\text { for } \mathrm{NaHCO}_{3} \text { equiv- } \\
\text { valent at } 25^{\circ} \mathrm{C} \\
(\Omega \mathrm{m})\end{array}$ & $\begin{array}{c}\text { Formation } \\
\text { factor }(F) \\
\left(F=R t / R_{u}\right)\end{array}$ & $\begin{array}{c}\text { True } \\
\text { resistivity } \\
(R t) \text { from ILD } \\
\text { at } 25^{\circ} \mathrm{C} \\
(\Omega \mathrm{m})\end{array}$ & $\begin{array}{l}\text { Porosity } \\
\text { (percent) }\end{array}$ \\
\hline 154 & - & $>40$ & 49 & $<.76$ & $>37$ & 14 \\
\hline 191 & - & $>220$ & 25 & $0.2-2.6$ & $5-65$ & 10.2 \\
\hline 219 & - & 220 & 21 & $0.4-3.0$ & $8-63$ & 13 \\
\hline 229 & - & 120 & 11 & $0.4-3.2$ & $4-35$ & 13.4 \\
\hline 247 & - & 27 & 9 & 2.9 & 26 & $13-16$ \\
\hline 257 & - & 39 & 21 & 1.8 & 37 & 11 \\
\hline 259 & - & 39 & 18 & .94 & 17 & 13 \\
\hline 262 & - & 57 & 22 & 2.5 & 54 & 11 \\
\hline 273 & 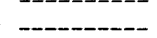 & 22 & 20 & 1. & 21 & 15.5 \\
\hline 278 & - & 39 & 20 & 1.9 & 38 & 16 \\
\hline 282 & - & 47 & 22 & 2.1 & 46 & 11 \\
\hline 289 & 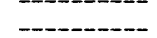 & 64 & 16 & 3.9 & 62 & 13 \\
\hline 306 & - & 75 & 21 & 3.5 & 73 & 11 \\
\hline 338 & - & 84 & 20 & 42 & 84 & \\
\hline 377 & - & 38 & 18 & 2.2 & 39 & $10 . \overline{1}$ \\
\hline 398 & - & 64 & 11 & 5.9 & 65 & 13.6 \\
\hline 413 & - & 65 & 19 & 3.5 & 66 & 8.3 \\
\hline 440 & $-0-1$ & 90 & 16 & 5.7 & 91 & 10 \\
\hline 468 & - & 47 & 25 & 1.9 & 48 & 13 \\
\hline 478 & - & 55 & 23 & 2.5 & 57 & 7 \\
\hline 508 & - & 190 & 33 & 6.1 & 200 & 5 \\
\hline 526 & 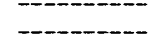 & 120 & $\begin{array}{l}00 \\
22\end{array}$ & 5.7 & 126 & 3 \\
\hline 570 & 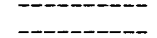 & 100 & 30 & 3.6 & 109 & 6 \\
\hline 582 & - & 140 & 19 & 7.9 & 150 & 7 \\
\hline 609 & - & 170 & 33 & 5.6 & 184 & -1 \\
\hline 633 & - & 130 & 24 & 5.8 & 140 & .8 \\
\hline 998 & - & 100 & 31 & 3.9 & 120 & .6 \\
\hline 1,019 & - & 130 & 15 & 12 & 180 & 0 \\
\hline 1,025 & - & 100 & 23 & 5.4 & 125 & 1.5 \\
\hline 1,042 & --- & 400 & 30 & 16.5 & 495 & -2 \\
\hline 1,057 & - & 380 & 28 & 16.6 & 465 & 0 \\
\hline 1,082 & - & 160 & 30 & 6.5 & 196 & -1.5 \\
\hline 1,101 & - & 150 & 29 & 6.4 & 185 & -2 \\
\hline 1,108 & --- & 200 & 31 & 8.1 & 250 & -3 \\
\hline
\end{tabular}

The spontaneous-potential and resistivity-log responses indicate that the water in the formations at the Sears No. 1 site increases vertically downward from 350 to 5,500 $\mathrm{mg} / \mathrm{L} T D S$. The consistent increase with depth also suggests that some circulation takes place throughout the depth of basin.

Average resistivity values for shale in the Sears No. 1 well ranged from about 40 to $50 \Omega \mathrm{m}$. Sandstones and conglomerates were found to have resistivities 5 to 10 times higher. The gamma-ray log indicated that most sandstones have gamma-ray values of from 50 to 80 API units.

Laboratory-measured values, which were used to check the accuracy of the borehole-geophysical log data, were important in determining other physical properties of rocks that could not be obtained from analysis of boreholegeophysical logs.

\section{SELECTED REFERENCES}

Ackerman, H.D., Bain, G.L., and Zohdy, A.A.R., 1976. Deep exploration of an east-coast Triassic basin using electrical resistivity: Geology, v. 4, no. 4, p. 137-140.
Alger, H.D., 1966, Interpretation of electric logs in fresh water wells in unconsolidated formations: Tulsa, Oklahoma, Society of Professional Well Log Analysts, 7th Annual Logging Symposium, May 8-11, p. CC1-CC5.

Anderson, E.M., 1951, The dynamics of faulting and dyke formation, with applications to Britain (2d ed.): Oliver and Boyd, $206 \mathrm{p}$.

Archie, G.E., 1942, The electrical resistivity $\log$ as an aid in determining some reservoir characteristics: Transactions, American Institute of Mining, Metallurgical, and Petroleum Engineers 146, p. 54-62.

Asquith, G.B., 1980, Log analysis by microcomputer: Penn Well Pub. Co., Tulsa, $105 \mathrm{p}$.

Avary, Lee, 1977, Clay mineralogy of the Durham basin: North Carolina University at Chapel Hill, North Carolina, $14 \mathrm{p}$.

Bain, G.L., 1973, Feasibility study of east coast Triassic basins for waste storage-data availability: U.S. Geological Survey open-file report, $113 \mathrm{p}$.

- 1977, Wrench-fault tectonic origin of east coast Triassic basins [abs.]: Geological Society of America Abstracts with Program, Southeastern Section, v. 9, no. 2, p. 115.

Bain, G.L., and Bisdorf, R.J., 1977, Structural reinterpretation of the Durham-Wadesboro basin, North Carolina [abs.]: Geological Society of America Abstracts with Program, Southeastern Section, v. 9 , no. 2, p. 116 .

Bain, G.L., and Brown, C.E., 1981, Evaluation of the Durham Triassic basin of North Carolina and techniques used to characterize its wastestorage potential: U.S. Geological Survey Open-File Report 80-1295, $132 \mathrm{p}$. 
Bain, G.L., and Harvey, B.W., 1977, Field guide to the geology of the Durham Triassic basin: Carolina Geological Society field trip guidebook, North Carolina Division of Mineral Resources, 83 p.

Bain, G.L., and Thomas, J.D., 1966, Geology and ground-water in the Durham area: North Carolina Division of Mineral Resources, GroundWater Bulletin 7, $147 \mathrm{p}$.

Bell, Henry, III, Butler, J.R., Howell, D.E., and Whallen, W.H., 1974, Geology of the Piedmont and Coastal Plain near Pageland, South Carolina, and Wadesboro, North Carolina: Soil Science State Development Board, Division of Geology (Carolina Geological Society Field Trip guidebook), $23 \mathrm{p}$.

Birch, F., 1942, Handbook of physical constants: Geological Society of America Special Paper 36, $325 \mathrm{p}$.

Brown, D.L., 1971, Techniques for quality of water interpretations from calibrated geological logs, Atlantic coastal area: Ground Water, July-August, v. 9, no. 4, 13 p.

Campbell, M.R., and Kinball, K.W., 1923, The Deep River coal field of North Carolina: North Carolina Geological and Economic Survey Bulletin 13, p. 25-28, 64-79.

Conley, J.F., 1962, Geology and mineral resources of Moore County, North Carolina: North Carolina Division of Mineral Resources Bulletin 76, $40 \mathrm{p}$.

Cornet, Bruce, 1977, The palynostratigraphy and age of the Newark super group: Pennsylvania State University, Ph.D. dissertation, 508 p.

Custer, R.L.P., 1967, Occurrence of limestones in the Durham Triassic basin [abs.]: Elisha Mitchell Scientific Society Journal, v. 84, no. 3, p. 176.

Gearhart-Owen, Inc., 1974, Formation evaluation data handbook: Fort Worth, $240 \mathrm{p}$.

Glaeser, J.D., 1966, Provenance, dispersal, and deposition environments of Triassic sediments in the Newark-Gettysburg basin: Pennsylvania Geological Survey Report G-43, 168 p.

Guyod, Hubert, 1944, Guyod's electrical well logging: Welex Bulletin A132, 103 p.

Hafner, W., 1951, Stress distributions and faulting: Geological Society of America Bulletin, v. 62, p. 373-398.

Harrington, J.W., 1951, Structural analysis of the west border of the Triassic basin: Geological Society of American Bulletin, v. 62, no. 2, p. $149-158$.

Hooks, W.G., and Ingram, R.L., 1955, The clay minerals and the iron oxide minerals of the Triassic red beds of the Durham basin, North Carolina, American Journal of Science, v. 253, p. 19-25.

Hubbert, M.K., 1951, Mechanical basis for certain familiar geologic structures: Geological Society of America Bulletin, v. 62, p. 335-372.

Keys, W.S., Eggers, D.E., and Taylor, T.A., 1979, Borehole geophysics as applied to the management of radioactive waste-Site selection and monitoring, in Carter, M.W., and others, eds., Management of low-level radioactive waste: Elmsford, New York Pergamon Press, Inc., v. 2, p. 955-982.

Keys, W.S., and MacCary, L.M., 1971, Application of borehole geophysics to water-resources investigation: Techniques of WaterResources Investigations of the United States Geological Survey, book 2, chap. E-1, 126 p.

Klein, G., deV., 1969, Deposition of Triassic sedimentary rocks in separate basins, eastern North America: Geological Society of American Bulletin, v. 80 , p. $1825-1832$

Krynine, P.D., 1950, Petrology, stratigraphy, and origin of the Triassic sedimentary rocks of Connecticut: Connecticut Geological and Natural History Survey Bulletin, v. 73, 247 p.

Marine, I.W., and Siple, G.E., 1974, Buried Triassic basin in the central Savannah River area, South Carolina and Georgia: Geological Society of America Bulletin, v. 85, p. 311-320.

McKee, E.D., and others, 1959, Paleotectonic map of the Triassic systems: U.S. Geological Survey Miscellaneous Geological Investigations Map 1-300, 33 p., 9 pls.
McKinstry, H.E., 1953, Shears of the second order: American Journal of Science, v. 251, p. 401-414.

Moody, J.D., and Hill, M.J., 1956, Wrench-fault tectonics: Geological Society of America Bulletin, v. 67, no. 9, p. 1207-1246.

Parker, J.M., III, 1978, The geology and mineral resources of Wake County, North Carolina: North Carolina Division of Mineral Resources Bulletin 86, $122 \mathrm{p}$.

Patterson, O.F., III, 1969, The depositional environment and paleoecology of Pekin Formation (Upper Triassic) of the Sanford Triassic basin, North Carolina: Unpublished Master's thesis, North Carolina University at Raleigh, North Carolina, $104 \mathrm{p}$.

Peterson, M.N.A., and von der Broch, C.C., 1965, Chert: Modern inorganic deposition in a carbonate precipitating locality: Science, v. 149, p. 1501-1503.

Prouty, W.F., 1931, Triassic deposits of the Durham basin and their relation to other Triassic basins of Western United States: American Journal of Science, 5th ser., v. 21, p. 473-490.

Randazzo, A.F., and Copeland, R.E., 1975, The geology of the northern portion of the Wadesboro Triassic basin, North Carolina: Southeastern Geology, v. 17, no. 3, p. 115-138.

Randazzo, A.F., Swe, W., and Wheeler, W.H., 1970, A study of the tectonic influence in Triassic sedimentation-The Wadesboro basin, central Piedmont: Journal of Sedimentary Petrology, v. 40, no. 3, p. 998-1006.

Reinemund, J.A., 1955, Geology of the Deep River coal field, North Carolina: U.S. Geological Survey Professional Paper 246, 159 p.

Russell, I.C., 1892, The Newark system: U.S. Geological Survey Bulletin 85,344 p., 13 pls.

Sanders, J.E., 1963, Late Triassic tectonic history of northeastern United States: American Journal of Science, v. 261, p. 501-524.

Schlumberger, Ltd., 1972, Log interpretation, Volume I-Principles: Schlumberger Limited, New York, 113 p.

-1974, Log interpretation, Volume II - Applications: Schlumberger Limited, New York, 116 p. 1977, Log interpretation charts: Schlumberger Limited, New York, $83 \mathrm{p}$.

Shearer, R.D., 1927, A cross section through the Triassic basin: Unpublished Master's thesis, University of North Carolina at Chapel Hill, $23 \mathrm{p}$.

Sumner, J.R., 1977, Geophysical investigation of the structural framework of the Newark-Gettysburg Triassic basin, Pennsylvania: Geologicial Society of America Bulletin, v. 88, p. 935-942.

Vilbrant, F.C., 1927, Oil-bearing shales of Deep River valley: North Carolina Division of Mineral Resources Bulletin, Economic Paper $59,23 \mathrm{p}$.

Whitehead, J.W., 1962, The petrology of the Sanford basin Triassic sediments, North Carolina: Missouri University, M.S. thesis, 174 p.

Wilcox, R.E., Harding, T.P., and Seely, D.R., 1973, Basic wrench tectonics: American Association of Petroleum Geologists Bulletin, v. 57, p. 74-96.

Woodworth, J.B., 1902, The Atlantic coast Triassic coal fields: U.S. Geological Survey, 22d Annual Report, pt. 3, p. 25-53.

Wyllie, M.R.J., 1963, The fundamentals of well log interpretation: Academic Press, New York, 238 p.

Wyllie, M.R.J., Gregory, A.R., and Gardner, L.W., 1956, Elastic wave velocities in heterogeneous and porous media: Geophysics, v. 21, no. 1, p. 41-70.

1958, An experimental investigation of factors affecting elastic wave velocities in porous media: Geophysics, v. 23, no. 3, p. 459-493.

Zohdy, A.A.R., 1974, The use of Dar Zarrouk curves in the interpretation of VES data: U.S. Geological Survey Bulletin 1313-D, 41 p.

Zohdy, A.A.R., and Bisdorf, R.J., 1975, Computer programs for the forward calculation and automatic inversion of Wenner sounding curves: National Technical Information Service, PB-247265/AS, Springfield, Virginia. 